\title{
Economía y organización político-social en la repoblación de Copapayo: un todo dificil a dividir.
}

\section{Introducción}

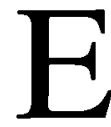

ste artículo hace referencia a una investigación de campo realizada en la repoblación de Copapayo (municipio Suchitoto, departamento Cuscatlán) en el periodo comprendido entre agosto y noviembre de 1992 y a la sucesiva elaboración de las informaciones recogidas luego de una reflexión y a una profundización teórica, bibliográfica.

Se reconstruye la historia de Copapayo una repoblación nacida a la orilla del embalse del Cerrón Grande, en una zona controlada por el FMLN, desde octubre de 1987. En esta fecha regresaron colectivamente a sus lugares de origen más de 1200 campesinos que en años anteriores se refugiaron en Honduras, en el campamento de Mesa Grande, para huir de las masacres, los bombardeos y los operativos militares que la "política de tierra arrasada" del gobierno estaba desarrollando en las zonas conflictivas. Al grupo de campesinos que fundó Copapayo se agregaron, en los años sucesivos familiares, ex-combatientes y desplazados, lo cual hizo crecer la comunidad. Al mismo tiempo muchos habitantes se fueron para establecerse en repoblaciones aledañas que surgieron a partir de 1990.

Por medio de historias individuales se recogieron elementos sobre los orígenes de la movilización política de estos campesinos, las modalidades de su involucramiento, las condiciones y motivaciones que los llevaron a incorporarse a la lucha armada.

Después de estas premisas "históricas" se analizó la peculiar organización económica de la comunidad, basándose en las siguientes preguntas: ¿Cuáles son las principales características de la vida económica de Copapayo? ¿Qué ha cambiado con respecto a la vida de estos campesinos antes de la guerra? Y sobre todo: ¿Cuáles son las relaciones entre la "economía" y la "sociedad", es decir, entre cómo se manejan, se mueven y se aprovechan los recursos disponibles y la 
organización política y social? ¿Y cuáles son las instituciones que están desarrollando una importante función económica?

Se investigaron, al mismo tiempo, las actitudes de los individuos frente a estas instituciones y frente a las relaciones económicas por ellos entrelazadas, ya que el "punto de vista del actor" contribuye mucho a moldear las relaciones económicas y sociales y, en lo general, la realidad comunitaria.

Se estudiaron en particular las actitudes de los individuos hacia la cooperativa, el trabajo colectivo y la organización comunitaria ya que se quería averiguar la posibilidad de que las repoblaciones, y en especial Copapayo, pudieran constituir una alternativa viable de desarrollo rural en El Salvador y en el Sur del mundo. Una alternativa que aprovechara de las potencialidades latentes en la organización política y económica a nivel comunitario y en la relativa disponibilidad de recursos para estos campesinos, debido al largo proceso de lucha política y militar a la cooperación internacional.

Para descubrir si Copapayo era vista o no como "alternativa" económica y social por parte de sus habitantes se investigó su percepción del cambio sucedido (¿Cómo era su vida antes de la guerra, sobre todo a nivel económico? ¿Era diferente de ahora? ¿Porqué? ¿Era mejor o peor? ¿Porqué?) y su percepción de las ventajas y desventajas de vivir en Copapayo. (¿Cuáles ventajas eran percibidas? ¿Derivaban de la organización comunitaria o no?)

Además se estudió si la actitud de los individuos era favorable a un desarrollo económico basado en la organización colectiva, la cooperación y la solidaridad.

Se complementó el punto de vista de los habitantes de Copapayo, y de su junta directiva, con el de las organizaciones políticas y gremiales -regionales y nacionales - con un estrecho enlace con la comunidad (el partido del Frente, el organismo regional que representa a esta y otras comunidades, la federación de cooperativas, etc...): ¿Cuáles ideas tenían estas organizaciones sobre el desarrollo de Copapayo?

La investigación fue de tipo cualitativo, tanto en sus supuestos teóricos como en la metodología utilizada.

Por lo que concierne a la metodología, la observación participante, las entrevistas formales e informales y las pláticas cotidianas fueron las "herramientas" utilizadas para conocer la realidad vivida por estos campesinos.

La elección epistemológica del método cualitativo era la más adecuada para el contexto que se iba a estudiar: una realidad comunitaria desconocida, compleja, anómala con respecto a un hipotético modelo de comunidad campesina, en condiciones precarias y de continuos cambios.

La dificultad de comprender esta realidad mudable y compleja no fue la única. Por ejemplo, había que enfrentar el particular papel otorgado por la po- 
blación a los extranjeros y enfrentar la necesidad de una "mediación" para poder acceder a la comunidad.

Otro problema fue el tiempo: los tiempos planificados casi siempre se demostraban inadecuados. Fue necesario más tiempo de lo planteado para acceder a la comunidad, para lograr un encuentro con la junta directiva, para conocer las personas antes de entrevistarlas, para entender qué había que preguntar, etc... Además la investigadora se encontró, por diferencias culturales, frente a una concepción y un uso del tiempo muy diferentes al suyo.

La experiencia enseñó, por un lado, que no se puede programar una investigación de este tipo antes de encontrarse en el lugar donde se va a realizar y hay que ser muy "flexibles", saber cuestionar el propio proyecto y saber "improvisar". Por otro lado, que tres meses de vida en la comunidad eran muy pocos para cumplir con el trabajo que había planteado, así que los objetivos de la investigación fueron definidos otra vez. Algunos temas fueron limitados, otros fueron analizados de manera superficial y entrevistando menos personas de las que se hubiera querido.

En este artículo se desarrolla el tema de la caracterización de la economía de Copapayo y de su relación con la organización política y social, exponiendo el enfoque teórico que se utilizó para el análisis.

El planteamiento teórico considerado el más adecuado al contexto es de Karl Polanyi, según el cual no se puede analizar una economía separándola de la organización social y política en la cual está insertada. El subraya la imposibilidad de anular, en el análisis de toda economía, tanto las particularidades históricas (estructurales y coyunturales) de cada sociedad como los significados extraeconómicos (individuales y colectivos) de los comportamientos económicos.

\section{El enfoque teórico: Karl Polanyi y la definición "substancial" de economía.}

\subsection{La "economía substancial" y la crítica a la "economía formal".}

Para poder analizar la economía de Copapayo, primero hay que definir qué se entiende por "economía". Se hace referencia a la definición de Karl Polanyi: la economía, es decir cada sistema económico concreto, es “...un proceso institucionalizado de interacción entre el hombre y su medio ambiente, que da vida a un continuo flujo de medios materiales para la satisfacción de las necesidades". ${ }^{2}$ Esto significa que:

- El objetivo de toda actividad económica es la satisfacción material de las necesidades humanas, sean éstas materiales o inmateriales. Es decir que lo "material" no se refiere a las necesidades, sino al hecho de utilizar medios materiales para satisfacerlas. (Ej. rezar no es actividad económica pero canalizar recursos en una fiesta religiosa sí lo es.). ${ }^{3}$ 
- El hecho de hablar de proceso lleva a un análisis en términos de movimiento. Los movimientos que constituyen el proceso económico pueden ser físicos o apropiativos. Los primeros se refieren al traslado físico de los objetos en el espacio (como en la producción y en el transporte); los segundos se refieren a su paso de una mano a otra, o sea a la circulación y administración de los medios materiales.

- Hay que subrayar que se trata de un proceso institucionalizado es decir incorporado en instituciones económicas y no económicas que le confieren su unidad y estabilidad; "...ésto da vida a una estructura que desarrolla una específica función en el seno de la sociedad; transfiere el proceso dentro de la sociedad proporcionando así un significado a su historia; orienta el interés hacia los valores, las motivaciones y las elecciones políticas". ${ }^{4}$

Las instituciones que constituyen la base del proceso son económicas y de otra índole (como religión, gobierno, etc.) La presencia de éstas últimas es muy importante. Además, las instituciones no se pueden considerar como simples agregados de comportamientos individuales, sino que presuponen la existencia de estructuras determinadas que dan un sentido social y una regularidad a los comportamientos y movimientos económicos. Este aspecto es fundamental, porque "...hasta que no se hayan indicado las condiciones sociales de las que surgen las motivaciones individuales, faltarían en gran parte o del todo los elementos capaces de explicar la interdependencia de los movimiento y su repetición, sin los cuales la unidad y la estabilidad del proceso terminarían. Los elementos naturales y humanos en interacción no constituirían una unidad coherente. En realidad, no se podría hablar de una entidad estructural que desarrolle una función en la sociedad y tenga su propia historia". 5

- Finalmente, la economía es un proceso de interacción entre el hombre y su medio ambiente. La explicación es muy sencilla: cada ser humano depende para su sobrevivencia de la naturaleza y de sus semejantes, por lo tanto se relaciona con su medio natural y social para satisfacer sus necesidades.

Esta definición expresa un significado substancial de economía y, en cuanto tal, se opone a su significado formal, cuestionando su pretensión de universalidad.

El significado substancial de economía es el "mínimo común denominador", válido para todas las sociedades, dado que todas necesitan de un ordenamiento estructurado de algún tipo para el abastecimiento de bienes y servicios. Esta es una necesidad imprescindible para cualquier vida personal y comunitaria.

Dicho en otras palabras, las economías, aunque puedan ser muy distintas entre sí por su diferenciación profunda en su institucionalización específica, tienen en común tres características fundamentales:

1. Cualquier tipo de grupo humano está constituido por gente que necesita comer y adquirir o producir bienes y servicios especializados para sostener la 
vida social y comunitaria (ej. religión, defensa, etc.); la adquisición y la producción de estos bienes y servicios necesarios a la existencia física y social nunca son dejadas a la casualidad porque la privación equivale a la muerte. Así, toda sociedad necesita de ordenamientos estructurados y reglas obligatorias para el abastecimiento y producción de bienes y servicios.

2. Todas las economías se aprovechan de los recursos naturales (tierra), de la cooperación humana (división del trabajo) y de la tecnología (herramientas y conocimientos). Estos tres elementos son reunidos para producir bienes y servicios en forma continua y duradera, por medio de la organización o estructura económica.

3. Emplean instrumentos económicos aparentemente similares -pero con un papel económico y social diferente según la sociedad- como lugares de mercado, objetos monetarios, contabilidad, relaciones de intercambio con el exterior.

Obviamente las diferencias entre las economías se deben a su dimensión, a su entorno físico y al hecho de funcionar en sociedades y culturas distintas.

Por lo que concierne al significado formal de economía, éste" ...se deriva del carácter lógico de la relación medios-fines, como es expresado en el empleo de términos como "económico" o "economizar". Este se refiere a un caso típico de elección entre distintos empleos a los que destinar los medios; elección necesaria porque tales medios existen en medida insuficiente. [...] Los dos significados fundamentales del término "económico" no tienen nada en común. El primero tiene una base factual, el segundo una base lógica. El significado formal implica la existencia de un sistema de reglas que se refieren a la elección de usos alternativos a los que destinar medios escasos; el significado susbstancial no implica ni una elección, ni una idea de escasez...".

La economía formal se basa en la combinación de dos elementos: la acción racional (que no se refiere a los fines, ni a los medios, sino a la relación entre los dos, o sea la elección de los medios más adecuados para los fines) y el postulado de escasez (insuficiencia de los medios). Pero no necesariamente en las economías reales se combinan estos dos elementos: hay que referirse a la economía de mercado, porque "...la economía se encarna en este caso en instituciones que permiten que las elecciones individuales den origen a movimientos independientes que constituyen el proceso económico. Esto es debido a la generalización de mercados regulares de precios. Todos los bienes y los servicios, incluyendo el empleo del trabajo, de la tierra y del capital, pueden ser adquiridos en un mercado y reciben por lo tanto un precio [...] La introducción general del poder de compra como medio de apropiación transforma el proceso para satisfacer las necesidades en asignación de medios insuficientes con usos alternativos, en particular el dinero. La consecuencia es que tanto las condiciones como las consecuencias de la elección son cuantificables bajo la forma de precios".? 
En efecto, la economía formal, y la ciencia económica en que ésta se fundamenta surgieron como producto y como teoría explicativa de la economía de mercado. Su marco histórico fue la revolución industrial y el desarrollo del capitalismo en Inglaterra, a partir de la segunda mitad de 1700. Los autores a quienes nos referimos son los fundadores de la economía clásica y, sucesivamente, de la economía neoclásica. Con ellos nació la ciencia económica como tal y se estudió, por primera vez, la economía como algo autónomo y separado de la sociedad.

A nivel político, la propuesta es la política liberal. La economía tiene sus leyes y no necesita la intervención del Estado, porque éste sólo obstaculizaría su desarrollo. A nivel filosófico, se plantea la centralidad del "hombre económico" y del individualismo utilitario. La sociedad es un agregado de individuos cuyas acciones son determinadas por sus intereses económicos individuales. Ellos obran racionalmente para conseguir el máximo de su utilidad. Claramente, estos planteamientos son el espejo de la situación histórica en los que surgieron: el capitalismo naciente en Inglaterra necesitaba de una política económica y de una justificación ideológica adecuadas para poder desarrollarse. ${ }^{8}$ Además, la economía formal fue el producto teórico de la tendencia histórica de la economía a desarrollarse y a separarse por primera vez de las instituciones políticas y sociales en las que estaba insertada. Esto es evidente en la transformación del trabajo y de la tierra en mercancías, que según Polanyi es el elemento clave para explicar como se pudo llegar a una "sociedad de mercado", o sea a una subordinación de la sociedad a la economía de mercado. "El punto crucial es éste: la mano de obra, la tierra y el dinero son elementos esenciales de la industria; también deben organizarse en mercados; en efecto, estos mercados forman una parte absolutamente vital del sistema económico. Pero [...] estos elementos no son mercancías, de acuerdo con la definición empírica de una mercancía. El trabajo es sólo otro nombre para una actividad humana que va unida a la vida misma, la que no se produce para la venta sino por razones enteramente diferentes; ni puede separarse esta actividad del resto de la vida, almacenarse o movilizarse. La tierra es otro nombre de la naturaleza, lo cual no ha sido producida por el hombre; por último el dinero es sólo un símbolo del poder de compra [...] Sin embargo, es con el auxilio de esta ficción que se van organizando los mercados de mano de obra, tierra y dinero [...]. Por lo tanto, la ficción de la mercancía provee un principio de organización vital en lo referente al conjunto de la sociedad, afectando casi todas sus instituciones en la forma más variada".?

Pero Polanyi cuestiona la universalidad de la economía formal no solamente estudiando su origen e incorporándola en un especifico contexto histórico, sino también por medio de una análisis comparativo: basándose en estuḍios históricos y antropológicos, quiere demostrar que, a excepción de la economía de mercado, todas las otras economías no se pueden analizar utilizando los principios de la economía formal. Estas son, en síntesis, sus principales argumentaciones: 
1. Adam Smith se equivocó en suponer una propensión natural del hombre hacia el trueque y el intercambio y en suponer que la división del trabajo surgió de ésta propensión.

La división del trabajo, un fenómeno tan antiguo como la sociedad, surgió desde diferencias concernientes el sexo, la geografía y las capacidades individuales.

2. Como ya planteaba Aristóteles, el hombre es un ser social, no económico. Más que defender su interés individual para la adquisición de bienes materiales, él mira el consenso social, a su estatus social, a las ventajas sociales.

3. En este sentido el principio utilitarista se impuso como razón principal de la participación de los individuos a las actividades económicas sólo con la afirmación de la economía de mercado. ${ }^{10}$ Por primera vez el hambre y la ganancia constituyeron los principales incentivos a la producción. La relación entre la producción y estos dos incentivos fue medida por la necesidad de conseguir un ingreso para poder sobrevivir. Estas motivaciones económicas no son elegidas libremente por los individuos, sino que son impuestas institucionalmente, en la medida en que son necesarias para el funcionamiento del sistema de mercado.

4. Sin embargo, según Polanyi, este proceso de subordinación de la sociedad al mecanismo de mercado no puede llegar a sus últimas consecuencias porque llevaría al aniquilamiento de la sociedad misma, dado que se destruirían completamente tanto las instituciones culturales que protejen a los individuos como al medio ambiente. En este sentido, él subraya como en los siglos XIX y $\mathrm{XX}$ los Estados se han hecho cargo de implementar, en los países industrializados, algunas "contramedidas" (como el proteccionismo y las políticas sociales) frente a la degeneración causada por la supeditación de la sociedad a la economía. En esta óptica, hasta el Welfare-State sería una respuesta a la amenaza de destrucción representada por la economía de mercado.

5. En las sociedades no capitalistas la economía está incorporada en las relaciones sociales y las motivaciones de los comportamientos económicos no son económicas. " Polanyi proporciona muchos ejemplos en este sentido, que van desde las economías primitivas, (como las tribus de las islas Trobriand o los Kula) y arcaicas (como la antigua China, el Imperio de los Incas, los reinos de India o el reino de Hammurabi en Babilonia), hasta las modernas economías de Unión Soviética, del Welfare State y de los fascismos europeos.

Entonces, ¿cómo estas sociedades garantizan el orden y la continuidad en la producción y distribución? La respuesta de Polanyi es que el principio de intercambio de mercado no es el único existente. Una economía puede estar integrada también por los principios de la reciprocidad y de la redistribución. ${ }^{12}$ 


\subsection{Las tres formas de integración de la economía y los significados extrae- conómicos de los comportamientos económicos.}

Reciprocidad, redistribución e intercambio son los tres principios de comportamiento económico que integran las economías, o sea son las tres formas de integración económica conceptualizadas por Polanyi para explicar la interdependencia, la articulación y la estabilidad de las partes que constituyen todo sistema económico concreto.

La reciprocidad se refiere a movimientos entre puntos correlacionados de grupos simétricos. Hace referencia al desarrollo de una prestación por parte de un sujeto (individuo o grupo) en favor de otro sujeto, simétrico, sin que el primero espere recibir por el segundo una prestación equivalente. Quien otorga la prestación da por hecho que cuando él necesitará algo será ayudado por quien ahora es beneficiado; el bien o servicio que le otorgará no será equivalente al de ahora, sino adecuado a la situación futura.

Max Weber expresa bien este principio cuando define la ayuda mutua entre los vecinos de una comunidad rural como "...producto del originario principio fundamental de la poco sentimental ética popular: como tú a mí, así yo a tí [...]. En efecto cada cual podrá encontrarse en la situación de necesitar el socorro ajeno". ${ }^{13}$

La manifestación típica de la reciprocidad es la donación, pero también son sus expresiones el auxilio gratuito en el trabajo, la asistencia a los discapacitados y los viejos o el préstamo desinteresado, es decir cada forma de prestación gratuita, en servicios o bienes, que es obligatoria en cuanto dada por supuesta.

La redistribución indica movimientos apropiativos en dirección de un centro y sucesivamente procedente de éste. Hace referencia a la presencia de una autoridad central, política o religiosa que recoge los recursos y después los reparte según criterios políticos o, mejor dicho, "según costumbres, leyes o decisiones tomadas por el centro."14

Mientras que la reciprocidad tiene un matiz social y expresa la idea de simetría, la redistribución tiene un matiz político y expresa la idea de centralidad.

La redistribución puede significar que la autoridad central recibe pagos obligatorios que emplea para sustentarse, proporcionar servicios a la comunidad o tener una escolta de emergencia, pero también puede significar que dicha autoridad tiene el derecho de disponer de los recursos, aunque no los recoja físicamente.

Finalmente el intercambio se refiere a movimientos bilaterales que se desarrollan entre dos manos en un sistema de mercado. El matiz es estrictamente económico, en sentido moderno: se otorga una prestación a cambio de otra (generalmente en dinero) equivalente a ella y medida en términos de mercado. ${ }^{15}$

Dicho en otras palabras, el intercambio de mercado concierne a relaciones 
especificamente "económicas", mientras que la reciprocidad y la redistribución conciernen a relaciones que son expresión de obligaciones sociales, y por eso se consideran modos socioeconómicos de transacción.16 (Ver el cuadro 1).

Para poder funcionar, las formas de integración (o modos socioeconómicos de transacción) necesitan de su específica base institucional. (La reciprocidad se basa, por ejemplo, en la familia, el parentesco o el vecindario, así como la redistribución en una organización religiosa o política y el intercambio en mercados reguladores de precios). Además, como ya se ha subrayado, estas instituciones no son simples agregados de comportamientos individuales, sino que se fundamentan en estructuras específicas. "Los comportamientos de reciprocidad entre individuos integran la economía sólo si existen estructuras organizadas simétricamente, como los sistemas simétricos formados por parientes. Pero para que se pueda afirmar un sistema de parentesco no es suficiente que a nivel personal los individuos mantengan un comportamiento de reciprocidad. Lo mismo vale para la redistribución. Esta presupone la existencia de un centro en la comunidad que asigne los recursos, pero para que tal centro se organice y logre una convalidación, no es suficiente que se den frecuentes reparticiones entre los individuos. Finalmente, lo mismo vale en el caso de los sistemas de mercado. Los actos de intercambio a nivel personal producen precios sólo si ocurren en mercados reguladores de precios, es decir en un orden institucional que nunca podrá surgir por actos casuales de intercambio". ${ }^{17}$

Hay que destacar que las formas de integración no representan "estadios" del desarrollo, no implican ninguna secuencia temporal. Es cierto que en cada economía se puede detectar una forma predominante (ej. reciprocidad en las tribus de las islas Tobriand, redistribución en el socialismo soviético o intercambio de mercado en los Estados Unidos), pero generalmente a la par de la forma dominante existen otras formas secundarias distintas. $Y$ muchas veces una forma de integración adquiere mayor eficacia cuando consigue utilizar, como métodos subordinados, las otras dos formas. ${ }^{18}$

Por lo tanto es fácil encontrar, en las economías empíricas, las tres formas sobreponiéndose, mezclándose e interrelacionándose, sobre todo en nuestro tiempo, en que el sistema de mercado ha ido expandiéndose por el mundo entero.

La economía de Copapayo es un buen ejemplo en este sentido: allí se puede detectar la presencia y la interrelación de reciprocidad, redistribución e intercambio y es difícil decir cuál es la forma predominante. En efecto ésto depende del rubro económico considerado y de la caracterización socieconómica de cada familia. 


\section{Cuadro 1 \\ EI significado de las tres formas de integración}

\begin{tabular}{|c|c|c|c|}
\hline $\begin{array}{c}\text { Forma } \\
\text { de integración }\end{array}$ & Reciprocidad & Redistribución & $\begin{array}{l}\text { Intercambio } \\
\text { de mercado }\end{array}$ \\
\hline $\begin{array}{l}\text { Relación social } \\
\text { expresada por la } \\
\text { transacción }\end{array}$ & $\begin{array}{l}\text { Familia y parentesco } \\
\text { Vecindad } \\
\text { Amistad } \\
\text { Estatus }\end{array}$ & $\begin{array}{l}\text { Afiliación } \\
\text { política o religiosa }\end{array}$ & Ninguna \\
\hline Principio explicativo & Simetría & Centralidad & $\begin{array}{l}\text { Movimientos } \\
\text { bilaterales }\end{array}$ \\
\hline Matiz & Social & Político & Económico \\
\hline Ejemplo & Familia & Estado & Mercados \\
\hline de instituciones & Parentesco & Iglesia & \multirow[t]{4}{*}{ autorregulados } \\
\hline \multirow[t]{3}{*}{ con función económica } & Clan & Cooperativa & \\
\hline & $\begin{array}{l}\text { Asociaciones de } \\
\text { de ayuda mutua }\end{array}$ & $\begin{array}{l}\text { ONG } \\
\text { Organismos }\end{array}$ & \\
\hline & Compadrazgo & Internacionales & \\
\hline \multirow{3}{*}{$\begin{array}{l}\text { Ejemplo de Sociedad } \\
\text { en que predomina la } \\
\text { forma considerada }\end{array}$} & Tribu de las islas & Socialismo & \multirow{3}{*}{$\begin{array}{l}\text { Estados Unidos } \\
\text { Inglaterra }\end{array}$} \\
\hline & Tobriand & Incas & \\
\hline & $\begin{array}{l}\text { Guaraní de la Selva } \\
\text { amazónica }\end{array}$ & Dahomey & \\
\hline
\end{tabular}

\section{La aplicación de la teoría de Polanyi a la realidad de Copapayo}

\subsection{La economía de Copapayo: premisas}

Antes de describir como se estudió la economía de Copapayo utilizando los esquemas analíticos de Karl Polanyi, hay que analizar brevemente sus principales características. Es necesario subrayar que nos referimos a 1992, sin considerar los cambios que se han dado desde noviembre de 1992 hasta ahora. ${ }^{19}$

La economía de Copapayo en 1992 presentaba, en su conjunto, una estructura bastante anómala, debido a la combinación de los rasgos de una economía campesina y "periférica" con las peculiaridades inducidas por la guerra, la organización política y las ayudas extranjeras... o, más bien, por las reacciones de la comunidad frente a estos fenómenos.

\subsubsection{Una economía campesina}

Se está hablando de una economía campesina, donde la actividad económica fundamental es la producción agrícola y en casi todas las familias se trabaja la tierra. La sobrevivencia y los tiempos familiares dependen de esta actividad. El cultivo principal sigue siendo el maíz, como en los tiempos precolombinos. 
En una economía campesina el objetivo principal de la actividad agrícola es la subsistencia. Copapayo constituye uno de estos casos, en donde los cultivos para la comercialización (ej. ajonjolí) son marginales y no alcanzan a sustituir al maíz.

Hay muchos otro rasgos que caracterizan una economía y una sociedad campesina y que se han encontrado en Copapayo: el arraigo a la tierra y a las raíces - en cierta medida debilitado por la larga historia de despojo que afectó a estos campesinos y por su desplazamiento en el tiempo de guerra; la fuerza de la tradición $;{ }^{20}$ el control social de la comunidad sobre los individuos; ${ }^{21}$ la relación con la naturaleza; la división sexual del trabajo; la familia como unidad económica básica (unidad de producción, consumo y ayuda mutua); etc., pero en esta sesión no hay el tiempo de analizarlos. ${ }^{22}$

Antes de explicar porqué se habla de "economía periférica" y de evaluar algunas de las repercusiones debidas a la guerra, a la organización política y a las ayudas extranjeras, es necesario describir rápidamente la vida económica de los habitantes de Copapayo antes de la guerra, es decir al final de los años '70. ${ }^{23}$

Los entrevistados dicen en su mayoría que eran arrendatarios o minifundistas. Los primeros tenían que alquilar la tierra (con pago monetario o con parte de la producción), mientras que los segundos eran propietarios de una pequeña parcela, lo que le daba una mayor seguridad y autonomía; los dos pertenecían a la forma de producción campesina, caracterizada por la producción agrícola familiar para la subsistencia. No se trataba de una "economía campesina pura" (autárquica), porque estaba articulada al mercado por medio de la venta y la compra de productos y a menudo por medio de la venta estacional de su fuerza de trabajo en las plantaciones. Esto era necesario porque la escasez y esterilidad de la tierra (la mejor quedaba en mano de los grandes propietarios de los cultivos de exportación), el escaso o nulo acceso a los créditos para insumos, a la asistencia técnica, a la innovación tecnológica y a la sobrepoblación determinaban una situación de pobreza y subempleo que no podía garantizar la subsistencia de la familia. ${ }^{24}$

Pero algunos habitantes de Copapayo eran pequeños propietarios (poseían entre las 10 y las 50 manzanas de tierras, desarrollaban más la actividad de comercialización y contrataban a jornaleros), colonos o peones.

Los colonos, que iban disminuyendo con la progresiva modernización del agro, eran trabajadores que vivían en la hacienda y que en cambio de una vivienda y/o una parcela de tierra tenían que entregar al dueño parte de su cosecha y trabajar un número determinado de días sin cobro para la hacienda. La relación entre ellos y el patrón tenía rasgos feudales tanto a nivel productivo como a nivel social, fortalecida por el paternalismo, el compadrazgo y hasta la dependencia psicológica. 
En cambio los peones, (asalariados del campo), pertenecían a un modo de producción capitalista: para sobrevivir vendían su fuerza de trabajo en las plantaciones modernas (a producción intensiva), pero no siempre tenían trabajo fijo.

Esta breve descripción no pretende ser exhaustiva, pero aquí no se puede profundizar el análisis, ni considerar los cambios que se iban dando en los años '70 por la profundización del capitalismo y la consecuente depauperación y proletarización de los campesinos. Además, se han considerado estas categorías de campesinos como "tipos ideales weberianos", pero en la realidad difícilmente se encuentran estos tipos "puros". (Por ejemplo una hacienda que se moderniza aunque tenga colonos, empieza a contratar asalariados, $o$ a un arrendatario que después de años de trabajo consigue comprarse unas manzanas de tierra.... O también a los minifundistas que en verano se vuelven asalariados cuando trabajan en las plantaciones.

\subsubsection{Una economía periférica.}

En Copapayo se observó un escaso acceso a los medios de producción (créditos para insumos, asistencia técnica, maquinarias, tierras de buena calidad); una producción de subsistencia, sobre todo de granos básicos; un bajo nivel de los consumos y un escaso acceso a los servicios públicos (sociales). Por todas éstas características, se define esta economía - utilizando un concepto introducido en los años '50 por Prebish y que sucesivamente se difundió en América Latina ${ }^{25}$ - como periférica, en varios sentidos:

1. Pertenece a la "periferia" del mundo, o sea a un país subdesarrollado y dependiente de los países del "centro". La dependencia económica hacia el exterior de El Salvador resulta evidente aún sólo si se considera que es un país agroexportador, por lo tanto sus mejores recursos son invertidos en la producción y el comercio para la exportación y sus ingresos dependen de las fluctuaciones de los precios en el mercado mundial.

2. La mayoría de la población rural —incluida la del Copapayo- queda al margen de la producción agroexportadora y no recibe beneficios de ésta. Para sobrevivir vende su mano de obra barata en las plantaciones o cultiva granos básicos en la tierra que queda libre (generalmente poca y de peor calidad). Además, históricamente la pequeña producción de granos básicos ha quedado casi siempre al margen de las políticas de modernización agrícola y al margen del acceso a los créditos, a la asistencia técnica, a las innovaciones tecnológicas y a los favorables canales de comercialización. Así, dentro del agro salvadoreño se puede encontrar un fuerte dualismo estructural caracterizado por un "centro" (la producción agroexportadora) y una "periferia" (la producción de subsistencia) marginal y funcional al centro, sobre todo porque cubre el consumo alimentario interno y proporciona, por medio de estos semi-proletarios, mano de obra estacional barata. 
3. Finalmente el tercer "centro" de esta periférica economía campesina es la ciudad. En primer lugar por el matiz "urbano" e "industrial" de las políticas de desarrollo y en segundo lugar porque la diferencia entre los precios de los granos básicos y los otros productos determina una explotación del campo por parte de la ciudad.

\subsubsection{Los efectos de la guerra.}

La guerra afectó directamente a la población de Copapayo por vivir en una zona conflictiva. Para todos significó una interrupción de su vida normal, huyendo a Honduras, trasladándose a otras zonas de El Salvador o incorporándose a la guerrilla.

Con respecto a los efectos socioeconómicos de la guerra, el más evidente es la gran destrucción de recursos humanos y materiales ${ }^{26} \mathrm{y}$, por otro lado, la nueva disponibilidad de recursos como consecuencia de las ayudas extranjeras y de los Acuerdos de Paz.

Pero hay también muchos otros efectos económicos indirectos, como: la desarticulación social debida al desplazamiento (que incluye tanto las relaciones de producción como las relaciones sociales. Por ejemplo, aquellas vinculadas al parentesco y al vecindario); y la rearticulación social ocurrida en los refugios y en la nueva repoblación, en ambos casos por medio de una peculiar organización; los efectos de la emigración definitiva al extranjero de muchos individuos; la influencia de las ayudas en los comportamientos económicos; la organización política por la pertenencia al Frente; los efectos psico-sociales del conflicto y las consecuencias negativas en el bienestar físicos y psíquico de las personas. ${ }^{27}$

\subsubsection{Los efectos de las ayudas extranjeras}

Una consecuencia de la guerra que se debe mencionar es la llegada de ayudas extranjeras, tanto en el refugio en Honduras (donde la gente dependía completamente de esta asistencia económica para sobrevivir) como en la repoblación. Las ayudas tuvieron una gran importancia económica porque aseguraron por mucho tiempo la sobrevivencia de la población y aún más por haber proporcionado los recursos necesarios al arranque del desarrollo económico de la comunidad. ${ }^{28}$

Además se supone que las ayudas influyeron de otras dos maneras, contradictorias, en la economía de Copapayo. Por un lado habrían desanimado, junto a otros factores, la organización y la participación a las tareas colectivas, por el hecho de acostumbrar a la gente a "ser asistida", a recibir pasivamente lo necesario para sobrevivir sin tener que trabajar y también a desperdiciar los recursos. Además, la costumbre de recibir habría llevado a los individuos a participar a las actividades colectivas sólo en cambio de un incentivo económico. Por otro lado, las ayudas habrían permitido por un largo tiempo la participación misma, porque 
la gente no tenía que preocuparse de su sobrevivencia. (En este sentido, uno de los factores de la crisis de participación detectada en 1992 sería precisamente al término de la ayuda directa, así que la gente piensa en primer lugar en "defenderse" y deja en segundo lugar la participación a las tareas y actividades colectivas).

Las ayudas fortalecieron la organización también por incentivar la centralización y redistribución de recursos. ${ }^{29}$ (En efecto, en 1992 los principales recursos manejados por la organización colectiva procedían de ayudas, mientras que aquellos procedentes de la producción se administraban a nivel familiar). Como se analizará más adelante, la progresiva disminución y transformación de las ayudas (de materiales a financieras, de donaciones a créditos) ha venido limitando y transformando el papel económico de la directiva y, en general, de la organización comunitaria.

\subsubsection{Los efectos de la organización política.}

Finalmente la organización política, que aparece como uno de los factores y al mismo tiempo una de las consecuencias de la guerra civil, contribuyó mucho a moldear la peculiar economía de Copapayo.

Aunque la guerra tuvo una función muy importante en impulsar y reforzar la organización política, ésta ya existía antes en la zona y hasta se puede considerar como uno de los factores que intervienen en explicar el estallido de la guerra. ${ }^{30}$

En efecto, muchos habitantes de Copapayo entrevistados cuentan haber empezado a organizarse en los años '70 por medio de las reuniones bíblicas "concientizadoras" impulsadas por los padres progresistas y luego por medio de la incorporación en FECCAS (Federación de Campesinos Cristianos Salvadoreños). La lucha política para defender sus derechos se fue radicalizando por la fuerte represión y por el contacto con otros agentes políticos (sobre todo los estudiantes universitarios que se fueron al campo para "concientizar las masas rurales"), hasta que la situación se volvió imposible y se incorporaron a la lucha armada. ${ }^{31}$

Con la guerra, la organización se fue fortaleciendo bajo todos los perfiles militar, político, económico: era una necesidad para la misma sobrevivencia. En las zonas conflictivas -incluida aquella donde se encuentra ahora Copapayosurgieron los Poderes Populares Locales, comunidades organizadas a nivel político, social, económico y militar (con milicias para la auto-defensa de la población). ${ }^{32}$ La experiencia de los PPL en la zona terminó cuando la política de "tierra arrasada" implementada por las Fuerzas Armadas obligó a toda la población a huir hacia otros lugares más seguros o a expatriarse a Honduras.

Sin embargo en el refugio hondureño de Mesa Grande la experiencia organizativa continuó, hasta empezó por muchas personas que no procedían de los PPL. 
En el refugio, el organismo dirigente llamado "comité de campamento" dirigía la distribución de las ayudas, se ocupaba de las relaciones con ACNUR y con las Agencias internacionales, coordinaba las áreas de trabajo (educación, salud, producción, talleres, etc.) y enfrentaba los problemas que iban surgiendo entre la población. El trabajo de este comité era respaldado por los coordinadores de 10 carpas y por la participación de la gente a las actividades económicas y sociales. Para la organización estrictamente política era clandestina y abarcaba sólo las personas de reconocida pertenencia política.

Como la gente no tenía que preocuparse por su sobrevivencia y además no había casi tierra para cultivar, la mayoría se dedicó a su educación, aprendiendo a leer y escribir y/o asistiendo a cursos de capacitación en talleres artesanales (y también en salud y educación, para formar promotores de salud y maestros populares).

Todos estos conocimientos y también la misma experiencia organizativa fueron muy útiles cuando los refugiados regresaron a El Salvador, fundaron Copapayo y tuvieron que empezar otra vez la vida en sus tierras, "desde cero".

Desde 1987 comenzó a "arrancar" la nueva vida comunitaria, bastante difícil debido a la guerra. La necesidad de defenderse (y también de canalizar las ayudas para la sobrevivencia) reforzó la organización, pero al mismo tiempo obstaculiz6 el desarrollo económico de la comunidad.

Esta es en breve la historia organizativa de los habitantes de Copapayo.

En 1992, la planificación económica (de la que se volverá a hablar más adelante) se daba a varios niveles: nacional (con el Plan de Reconstrucción Nacional y su correspondencia a nivel municipal y con el proyecto del FMLN de desarrollo en las áreas ex-conflictivas), regional (en que se destacaba el papel del organismo PROGRESO) y comunitario.

A nivel comunitario, la organización política tenía su máxima expresión en la asamblea general y en la junta directiva elegida por los miembros de la asamblea.

En 1992 la junta directiva administraba las ayudas financieras recibidas por la comunidad y antes se había encargado también de cómo y cuándo repartir los alimentos y otros bienes que habían llegado. Además, había gestionado la construcción de las viviendas provisionales, de los otros edificios (escuela, guardería, clínicas, bodegas) y de la infraestructura (letrinas, agua). Se había encargado de organizar los servicios de salud, educación y transporte, los talleres artesanales, la cría de ganado para leche y el trabajo agrícola colectivo. En todas estas áreas, excepto la milpa colectiva y la limpieza de las letrinas, quien trabajaba recibía un salario por parte de la directiva, decidido por ésta o por medio de una "negociación" entre ésta y los trabajadores.

Además la directiva administraba los medios de producción agrícola: había 
repartido la tierra (de propiedad colectiva) a los campesinos según sus demandas y cada verano distribuía la tierra húmeda dejada por el lago; se ocupaba del préstamo de venenos, abonos y semillas; gestionaba la utilización del tractor y de otras maquinarias de la comunidad.

Resumiendo, en 1992 la organización política influía económicamente en dos ámbitos: en la distribución de los medios de producción y en la organización de las áreas de servicio -como educación, salud, transporte- y de producción para la comunidad (cría de ganado vacuno, artesanía, producción colectiva de maíz). Pero influía sólo directamente en la producción agrícola familiar y en los consumos a nivel familiar, los cuales eran decididos por cada familia.

Además ya se subrayó que por medio de la organización se había modificado la división del trabajo, por abrir nuevas oportunidades a muchos hombres y mujeres: campesinos y campesinas se volvieron maestros, promotores de salud, corraleros, camioneros, sastres y hasta dirigentes políticos, lo cual hubiera sido muy difícil antes de la guerra.

En conclusión, aunque se ha destacado la influencia de la guerra, de las ayudas y de la organización política en la economía de Copapayo, no se quiere excluir la presencia de otros factores, como por ejemplo la política económica o la aplicación de los Acuerdos de Paz, que desde 1992 hasta ahora han venido desarrollando un papel económico — directo e indirecto- muy importante para Copapayo.

Además, la separación de estos tres factores ha sido un "artificio" adoptado para facilitar el análisis, ya que muchos aspectos estudiados parecen derivar más bien de a interacción de estos factores (y otros más), los cuales a su vez se han influenciado recíprocamente.

\section{2.: Las necesidades de los habitantes de Copapayo.}

Hemos dicho que el objetivo directo o indirecto de todo proceso económico es la satisfacción de las necesidades humanas y que es difícil, sino imposible, definir algunas necesidades "objetivas" y "universales" para todos los seres humanos.

Por esta razón, al estudiar cómo la gente de Copapayo trataba de satisfacer sus necesidades, se decidió investigar sobre la percepción subjetiva de sus necesidades, pará luego compararla con el punto de vista de la investigadora.

Estos fueron los resultados de las entrevistas realizadas:

- La necesidad primaria para todos (enumerada como primera o segunda) era la alimentación, aunque los individuos no hablaran de "comida", sino de maíz, frijoles, etcétera. La necesidad se veía como algo muy concreto y no se separaba de las costumbres. Como ya se ha mencionado, "No es suficiente contestar que es necesario comer; se debe considerar qué, cómo y con quién una 
persona va a comer"....

- Casi todos mencionaban también la salud (o, más bien, las medicinas) y ésto es comprensible considerando la gran cantidad de enfermedades debido a las condiciones de vida y a las repercusiones de la guerra. La gente se quejaba de sus enfermedades no sólo porque le hacían estar mal, sino porque le afectaban económicamente por la imposibilidad de trabajar y por el gran gasto en medicinas. En efecto muchas familias gastaban todo su ahorro en la compra de éstas, por ser muy caras y también porque había mucha dependencia y abuso de fármacos. La idea era que más medicinas se tomaran, mejor uno se sentiría, y nunca éstas habrían podido hacer daño.

-Otra necesidad considerada fundamental era el amparo, en dos sentidos: ropa y habitación. (Varios hablaban de "casa digna", y en su definición parecían influenciados por la propuesta de CREA (una organización financiada por AID), que en ese tiempo había empezado a promover en la comunidad un proyecto de construcción de viviendas).

-Dos necesidades que planteó la investigadora pero que no eran percibidas por la gente fueron la educación y higiene. Al contrario, bastantes entrevistados mencionaron como necesidad una vaca o ganado. Esto hace reflexionar sobre como dos culturas y modos de vida distintos llevan a un diferente percepción de las necesidades fundamentales y también expresa la identidad campesina de los habitantes de Copapayo, quienes no conciben los medios de producción separados de los bienes de consumo o el trabajo separado del descanso, al contrario de un obrero o una secretaria.

Además para los campesinos poseer ganado es símbolo de bienestar y seguridad económica.

- El dinero era considerado una necesidad por menos de la tercera parte de los entrevistados y raramente ocupaba el primer lugar en el listado. Es interesante destacar que todos quienes lo mencionaban tenían una particular relación con el dinero, que era o había sido fuente de supervivencia (se trataba de algunas viudas que recibían ayudas financieras por parte de los hijos, de la esposa de un hombre asalariado por la comunidad y de otro hombre que antes de la guerra era peón). Pero la sobrevivencia de la mayoría de las familias de Copapayo estaba asegurada por la producción agrícola.

Esto parecía indicar que el "intercambio de mercado" era una forma presente en las relaciones económicas de Copapayo, pero no era la única ni la dominante. ${ }^{33}$

-Finalmente una respuesta bastante común era que "las necesidades son todas las cosas que sirven en la casa". ( $\mathrm{Y}$ a una ulterior pregunta, la gente empezaba a enumerar: maíz, frijoles, cal, ropa, trastes...). Esto evidenciaba el papel de la economía doméstica en la satisfacción de las necesidades: el hogar era unidad de producción, consumo y ayuda mutua. 


\subsection{El proceso de interracción de los individuos con el medio ambiente y con el medio social: producción y transporte; división del trabajo y transac- ciones económicas.}

Se ha dicho que en 1992 la producción en Copapayo era esencialmente agrícola (sobre todo maíz y, en menor medida, frijoles y ajonjolí). Esta era transportada desde los campos hasta las viviendas por la población y desde la comunidad hasta Suchitoto (la parte que se quería vender) por medio de camiones y lanchas de la comunidad (pagando).

Pero, además de la producción agrícola, se desarrollaba la cría de ganado, que tomaba tres formas: colectiva (administrada por la junta directiva y ejecutada por tres corraleros de la comunidad pagados por ésta); individual (o, mejor dicho, familiar) y cooperativa, que en 1992 estaba surgiendo.

Debido a la baja calidad de la tierra de Copapayo, el ganado era considerado por las instituciones que planteaban el desarrollo de la comunidad como la actividad que era necesario promover, mientras que la agricultura podría tener sólo el papel de garantizar la sobrevivencia. Además la tierra húmeda liberada por el lago en el verano proporcionaba no solo tierra húmeda para una segunda cosecha de maíz, sino también un buen pasto para los animales.

Esto lleva a la vital importancia para el campesino de su interacción con el medio natural y a cómo la degradación ecológica (agotamiento y contaminación de la tierra, contaminación del agua, desertización y consecuente escasez de agua, etcétera) está afectando a su economía, que depende del medio ambiente de manera mucho más directa que en el caso de la población urbana: él vive del producto de la tierra, se lava en el río, corta las ramas de los árboles para cocinar, va a pescar para tomar sopa y aguanta el hambre si no llueve. Puede parecer obvio, pero ni tanto si se observa como se está destruyendo el medio ambiente en El Salvador..

Respecto a la interacción social entre los individuos, se considerarán dos aspectos: la división del trabajo y los movimientos apropiativos (o sea las transacciones económicas), aunque en la realidad no estén separados entre sí.

La división del trabajo en Copapayo se desarrolla en el nivel familiar y comunitario. A nivel familiar la distribución de tareas es de tipo tradicional, o sea en base al sexo, con una separación casi absoluta entre tareas masculinas - vinculadas sobre todo a la producción - y tareas femeninas - vinculadas a la reproducción, como: preparar la comida, cuidar y educar a los hijos, cuidar y asear la casa, lavar, acarrear agua y leña, etc.

Esta división del trabajo, bien expresada por la frase bastante frecuente: "El varón se dedica al machete y la cuma y la hembra a la casa", no es diferente cuando en la pareja uno de los dos tiene otro trabajo. El hombre tratará de cultivar su milpa en el tiempo libre y con el apoyo de los hijos, a veces pagando 
peones o bien haciéndose ayudar por la esposa y las hijas (sobre todo en tareas específicas, como acarrear agua, tapiscar, transportar la cosecha. Pero las decisiones las toma siempre el hombre: el campo es su lugar). Así mismo, cuando la mujer tiene un trabajo fuera de la casa, tendrá que conciliarlo con el trabajo doméstico y se hará ayudar por las hijas (o bien la madre, la hermana, la cuñada...).

En este sentido, hay que destacar la importancia del trabajo de los hijos. Los varones empiezan desde niños a ayudar al padre en la milpa, para trabajar regularmente con él a los doce años (más o menos). Las hembras desde muy pequeñas comienzan a ayudar a la madre en las tareas de la casa y trabajan muchísimo, por una razón no sólo económica, sino también educativa: porque "tienen que aprender". Una madre quiere que su hija vaya haciéndose "buena esposa futura", porque si no cumple con sus tareas no es una buena mujer. La identidad de la mujer, moldeada por medio de la educación familiar, resulta tan vinculada a la división del trabajo familiar que una frase muy común es: "Una mujer que no puede tortear (hacer tortillas) no es una mujer".

Es cierto que las cosas han cambiado un poco en los últimos años. Por ejemplo, muchas mujeres dicen que antes de la guerra eran excluidas del todo de la administración de la economía doméstica, que no podían salir de la casa sin el permiso del hombre, que nunca iban a trabajar a la milpa, etc. Ahora es diferente: el desarrollo por parte de la mujer del papel de jefe de familia debido a los muchos hombres muertos y a la inestabilidad de la pareja, la incorporación de la mujer al trabajo comunitario y a la guerrilla, la experiencia en Honduras y todos los cambios debidos a la guerra y a la movilización política han modificado parcialmente la situación, pero se percibe una fuerte tendencia hacia el regreso a la situación de antes.

Así, hasta en la división del trabajo a nivel comunitario se puede encontrar la misma división de las tareas en masculinas y femeninas. En efecto, son exclusivamente hombres quienes desarrollan las tareas tradicionalmente a ellos asignadas, como: el trabajo agrícola (en forma colectiva y gratuita), la cría de ganado (en forma colectiva y cooperativa), la contabilidad, la carpintería, los transportes, el molino y sobre todo los cargos de responsabilidad y autoridad. Por otro lado, hay una mayoría de mujeres en el trabajo de salud, educación, sastrería, cocina y aseo (gratuito). Así que las mujeres, aún fuera de la familia, siguen ocupándose de sus tareas de siempre: educación, atención a los enfermos, cocina, limpieza...

División del trabajo significa también que cada uno proporciona a los otros una específica prestación (en bienes y servicios) y a cambio recibe otras por ellos, o sea que se dan transacciones de bienes y servicios entre los individuos. Pero ¿con cuáles criterios se realizan estas transacciones? Se desarrollan asumiendo los criterios de Polanyi- según los tres principios de comportamien- 
to económico antes analizados: la reciprocidad, la redistribución y el intercambio de mercado.

\subsection{La "reciprocidad": el papel primario de familia y parentesco. El papel secundario de vecindario, amistad y compadrazgo. ${ }^{34}$}

En Copapayo la institución fundamental en la cual toman forma las relaciones económicas de reciprocidad es la familia (cuya importancia cultural y social se destaca, por ejemplo, en la coincidencia de las expresiones "trabajo individual" y "trabajo familiar" o en la respuesta a la pregunta: “¿Cuánta gente está viviendo en Copapayo?", que es: "Somos 140 familias").

Las familias de Copapayo son en su mayoría extensas en cuanto abarcan más de un núcleo familiar (por ejemplo, la pareja con sus hijos y los padres de un cónyuge; o bien la pareja, sus hijos y la familia de un hijo; y a veces abarcan también hermanos o tíos de un cónyuge). Pero estas familias extensas son anómalas, ya que a menudo son un ensamblaje de más núcleos quedados incompletos por causa de la guerra. Así es fácil encontrar una viuda y sus hijos menores viviendo con la familia de su hijo mayor porque ella sola no logra sobrevivir. $O$ bien, podemos encontrar una mujer sola (viuda o abandonada) con sus hijos, viviendo con los padres o con la familia de una hermana... o también una persona quedada sola $-\mathrm{y}$ a veces lisiada - que vive con el (la) hermano (a), o el (la) nieto (a). O niños huérfanos que son criados por sus abuelos o sus tíos.

La guerra afectó la estructura y los equilibrios familiares tradicionales, cuestionándolos con la muerte, la incorporación en a guerrilla y la dispersión geográfica. Además hay que destacar la existencia de una fuerte inestabilidad de la pareja, seguramente aumentada por los elementos antes mencionados y —según algunos entrevistados - por la crisis de valores tradicionales como la indisolubilidad del matrimonio, la responsabilidad del padre frente a la familia, etc. En este sentido la guerra ha amenazado los lazos de solidaridad entre familiares. Por otro lado, la guerra misma los ha reforzado, también desde un punto de vista económico, porque frente a las extremas dificultades de sobrevivencia la gente se unió "para aguantar".

La relación de reciprocidad más importante a nivel familiar es sin duda aquella entre padres e hijos, tanto objetivamente como en la percepción de la gente entrevistada. Esto no sólo cuando los hijos forman parte del mismo núcleo económico de los padres, lo que es obvio, ${ }^{35}$ sino también cuando van a constituir su propia familia.

Según los padres, es natural "hacer sacrificios" para los hijos, así como es natural que ellos los ayudarán siempre y los asistirán cuando lleguen a viejos, ya que no podrán ser autónomos. Sin embargo ya antes de la vejez es muy importante la ayuda mutua entre padres e hijos. Por ejemplo, la mayoría de veces que un hombre necesita ayuda en su milpa lo pide a un hijo y madres e hijas se 
apoyan en las tareas del hogar.

Además de ésta forma de servicios gratuitos, la reciprocidad entre padres e hijos toma la forma de préstamos y donaciones de bienes que hasta pueden ser garantía de sobrevivencia para el más desfavorecido, como en el caso de muchas viudas que reciben productos alimentarios y dinero por parte de los hijos que viven en Copapayo o en otros lugares, sobre todo en San Salvador. En efecto es muy frecuente la ayuda económica por parte de hijos que viven en la ciudad y que por ésto tienen más disponibilidad financiera.

Dicho en otras palabras, la reciprocidad es garantía de sobrevivencia para personas y grupos familiares improductivos, como viudas, mujeres solas, huérfanos, ancianos, lisiados, que además del apoyo de la comunidad, ${ }^{36}$ encuentran aquello de los hijos, de los padres, o bien de los hermanos.

En efecto no hay que descuidar el papel económico de la ayuda entre hermanos, tanto con la mediación de los padres (un hijo que ayuda a la madre viuda ayuda también a su hermano menor) como en forma directa. Muchas personas reciben ayudas económicas por parte de los hermanos que viven en San Salvador y se intercambian favores con aquellos que viven en la comunidad. La relación entre hermanos parece reforzarse cuando mueren los padres, los cuales tienen la relación privilegiada con todos. (Ejemplar es la frase de una mujer que, hablando de su hermana, dice: "En ella tengo confianza y esperanza como si fuera mi mamá"). ${ }^{37}$

Tiene una cierta importancia también la relación entre suegro(a) y yerno (nuera) o entre cuñados (as), sobre todo si el vínculo familiar es respaldado por un lazo afectivo. Este tipo de relación económica se desarrolla sobre todo entre hombres o entre mujeres.

También hay que mencionar, aunque tiene mayor peso, el papel del parentesco. No obstante que los contactos entre muchos parientes se perdieron por causa de la guerra, los habitantes de Copapayo tienen relaciones con algunos parientes, que ven sobre todo en ocasión de fiestas importantes. Además las redes de parentesco entre los habitantes de Copapayo pueden facilitar la ayuda mutua sobre todo en préstamo y apoyo ocasional en el trabajo- pero ésto no es algo importante y cierto como en el caso de los familiares cercanos. (Ej. Un individuo puede tener una estrecha relación de solidaridad con un primo y no tenerla con otro).

Fuera de las relaciones de sangre, otra institución que en Copapayo tiene un papel, aunque ambiguo, en el desarrollo de las relaciones económicas de reciprocidad es el vecindario.

Es un papel ambiguo por varias razones. En primer lugar el desplazamiento surgido de la guerra destruyó las redes de vecindario preexistentes, dado que la mayoría de la población de Copapayo procede de ésta misma zona, pero de 
cantones y municipios diferentes. En 1987 la mayoría se encontró a vivir con gente extraña (y a menudo se estableció cerca de sus familiares, talvez para reconstruir la situación anterior). Según algunas personas, ésto explicaría la desconfianza, los líos y la falta de solidaridad que ellas detectan entre vecinos. En segundo lugar el concepto de "vecindario" puede indicar tanto las familias que viven cercanas como todos los miembros de la comunidad. En este segundo caso, el significado concreto de vivir en el mismo lugar se sobrepone al significado ideológico y político de "comunidad" que ha venido desarrollándose desde los años '70, con la concientización política y después con la guerra ("comunidad" en el sentido político de pertenencia y organización; "comunidad" en el sentido ético de solidaridad, unidad, fraternidad y cooperación). El significado ético y el político a menudo parecen sobreponerse (así, por ejemplo, el trabajo colectivo administrado por la directiva tiene el objetivo de producir el maíz para las viudas y los lisiados). Así como los dos parecen mezclarse con el tradicional principio ético campesino "como yo a ti, así tú a mi".

Entonces al hablar de "comunidad", la "reciprocidad" y la "redistribución", alianzas familiares y alianzas comunitarias, decisiones individuales y colectivas se sobreponen y al mismo tiempo se contraponen, dada la crisis de la organización, de la participación política y del trabajo colectivo.

Al contrario, si se consideran los vecinos como dos que viven en casas cercanas, se puede decir que la ayuda recíproca existente entre ellos consiste sobre todo en pequeños favores y préstamos y tiene generalmente un carácter de excepcionalidad. (Por ejemplo, las mujeres piden prestado maíz cocido a las vecinas si no han podido cocerlos o le piden que le cuiden la casa si tienen que salir). Mucha gente subraya que a los vecinos se piden pequeños favores mientras que los grandes favores se piden a los familiares. ${ }^{38}$

Otros dos tipos de relación que se han encontrado en Copapayo con respecto a la reciprocidad son la amistad y el compadrazgo.

La amistad tiene una cierta importancia económica para algunas personas, pero nunca precede ni sustituye a los familiares. Los amigos tienen un papel económico secundario y concerniente sobre todo al préstamo precario y al trabajo precario (gratuito) en casos de emergencia.

Al hablar del compadrazgo, una institución muy difundida en América Latina mediante formas diversas, aquí se hace referencia a la relación existente entre el padre o la madre de un niño(a) y su padrino o madrina de bautismo o de confirmación.

Esta relación puede ser de tipo vertical u horizontal (entre individuos con igual posición social: estatus, poder político, recursos económicos). En este segundo caso se establece entre compadres o comadres una relación simétrica.

En Copapayo parece prevalecer la relación horizontal por las siguientes hipo- 
téticas razones: porque las diferencias socioeconómicas no son muy fuertes; porque con la lucha política se difundieron los ideales de igualitarismo y cooperación que iban motivándola y que no han sido borrados todavía; y porque la guerra parece haber quitado fuerza a ésta institución. De todos modos la tendencia a la "relación vertical" existe todavía, así que hay gente que escoge como padrino o madrina de sus hijos las personas más rica y con más prestigio en la comunidad.

La función económica del compadrazgo no es importante: más que todo es una relación de respeto, estima y a menudo formal. Hay compadres y comadres que se intercambian favores, pero los rasgos económicos más evidentes son la promesa de ocuparse del ahijado en el caso que mueran los padres y la entrega de regalos a los ahijados en las fiestas más importantes (navidad, cumpleaños). Estos regalos (muchas veces juguetes o golosinas) parecen tener una función más que todo simbólica, expresando la idea de donación como alianza.

Este significado de la donación es muy importante, ya que lleva a suponer que en Copapayo las "alianzas" son significativas solamente cuando implican una cierta forma de ayuda concreta. (Por ejemplo, un buen hijo o un buen amigo es el que te ayuda; o una mujer ofrece tamales a las vecinas para tener con ellas buenas relaciones; o bien, la extrema gratitud de la gente frente a la iglesia católica y a los extranjeros sería debida a las ayudas económicas que han otorgado en el pasado...). Esto es útil para comprender el poder político, el consenso social y la influencia cultural que pueda tener una institución cualquiera que ayude económicamente a la comunidad.

En conclusión, aunque la percepción subjetiva de las personas y su concreta dependencia económica de las relaciones de reciprocidad varían de un caso a otro, se puede decir que:

- Todos reconocen la importancia económica de las relaciones entre familiares y sobre todo entre padres e hijos.

-El mecanismo de reciprocidad funciona siempre en el caso de asistencia a huérfanos, viudas, lisiados, ancianos, que nunca son abandonados a ellos mismos;

- generalmente la ayuda material por parte de familiares externos a la comunidad es importante no para la sobrevivencia (asegurada por medio de la producción agrícola), sino para tener acceso a bienes como ropa, utensilios de cocina y otras herramientas de la casa.

\subsection{La redistribución y el papel económico de la organización política, de las ayudas y de la cooperativa.}

En 1992, las instituciones que se detectaron en Copapayo como base del funcionamiento del mecanismo de redistribución (es decir cuando un centro ad- 
ministra los recursos y los reparte según diferentes criterios) fueron la organización comunitaria, la cooperativa, los organismos regionales y nacionales con enlaces políticos y económicos con la comunidad y las ayudas internacionales.

Como ya se ha subrayado, la organización comunitaria, por abarcar varios sectores y actividades, en 1992 tenía un papel económico importante, aunque era la producción agrícola familiar a garantizar la sobrevivencia y era la familia la institución que más respondía a la satisfacción de las necesidades básicas de los individuos.

Hay que destacar la transformación del papel económico de la organización comunitaria y de la directiva desde 1987 hasta 1992. La progresiva transición desde las ayudas directas en bienes de consumo y de producción hasta la sola financiación -más en forma de créditos que de donación- de proyectos de desarrollo productivo y de infraestructura había disminuido la importancia de la centralización y redistribución de los recursos y cambiado el papel económico de la directiva. En efecto, por un lado se implemento la iniciativa individual como garantía de sobrevivencia y por otro, el papel fundamental de la directiva iba haciéndose el impulso a las actividades económicas por medio de la administración e inversión de dinero, lo que necesitaba de operaciones mucho más difíciles que la simple distribución de bienes. Era (y es) todo un proceso de decisión que implicaba evaluaciones económicas, proyección hacia el futuro, involucramiento de la población a largo plazo y sobre todo mediación entre la población, con sus necesidades y expectativas, y las instituciones nacionales e internacionales que otorgaban la financiación. Un papel muy difícil, cuyo éxito no era cierto. Sin embargo, la directiva parecía cumplir un papel más ejecutorio que decisorio, ya que los proyectos de desarrollo eran elaborados por PROGRESO (el organismo de representancia regional) y por ONG salvadoreñas y extranjeras. La directiva más que todo tenía que garantizar la aceptación del proyecto por la comunidad y su implementación concreta.

Además, en 1992 empezaba otro proceso impulsado por los Acuerdos de Paz: el de la "reconciliación y reconstrucción nacional", con la difícil integración de los ex-combatientes y de las repoblaciones en la vida nacional. Por medio del Plan de Reconstrucción Nacional, Copapayo y las otras repoblaciones instauraban nuevas relaciones económicas y políticas con el gobierno, la alcaldía y otras instituciones, que durante la guerra habían representado los "enemigos" de la lucha político-militar. Esto implicaba para la directiva otro papel de mediación, aún más difícil.

$Y$ no se debe olvidar la dificultad de impulsar proyectos de desarrollo en un momento de transición y además de desmovilización general, en el cual la gente participaba menos o ya no quería participar en el trabajo colectivo y en las actividades comunitarias porque su principal preocupación era su situación económica familiar. En este sentido es elocuente la disminución progresiva de la 
producción colectiva de maíz entre 1988 y $1992 .{ }^{39}$

De esta rápida descripción es fácil destacar que, al considerar las dos principales autoridades de la organización comunitaria, la directiva tenía seguramente un papel decisional mucho más importante que la asamblea general, tanto que los mismos dirigentes admitían tener demasiadas responsabilidades. Ellos criticaban la actitud de quien se quejaba mucho pero dejaba toda responsabilidad a la directiva, como si la tarea de defender los intereses colectivos fuera exclusivamente de los dirigentes.

Esta actitud tiene varias hipótesis explicativas. Ante todo, hay una costumbre debida a la histórica exclusión de los campesinos de las oportunidades de participación política y del poder decisional, ya que frente a una postura política activa de los campesinos la respuesta ha sido siempre la represión. Esto, según varios autores, ${ }^{40}$ ha favorecido el desarrollo en las masas rurales de una actitud pasiva y apática como defensa frente a un medio cerrado, hostil y violento. Además la organización política en que los campesinos se involucraron en los años '70 y ' 80 tenía sus límites en cuanto a democratización interna, sobre todo durante la guerra (por obvias razones). $\mathrm{Y}$ aun se ha destacado que las ayudas reforzaron en cierto sentido ésta actitud de pasividad y de apatía, inhibiendo el activismo económico y político.

Pero es necesario preguntarse también: ¿Cuánto la gente percibía e identificaba como suyos los intereses colectivos? ¿Se sentía formar parte de la organización comunitaria o la percibía como algo ajeno?

Estas preguntas nos llevan al análisis de la percepción subjetiva de lo que es "redistribución", o sea de las actitudes hacia el trabajo colectivo y cooperativo, la participación política y la asignación de los recursos y del trabajo por la directiva.

La impresión de la investigadora es que la gente no pensaba participar, sino excepcionalmente, en las decisiones sobre asuntos económicos comunitarios. Quien decidía era la directiva, la cual tenía el control sobre la asignación de los recursos y de los puestos de trabajo. Además muchos pensaban que esta distribución no tenía criterios de equidad (por ejemplo, pensaban que los familiares de los dirigentes tenía privilegios).

Las formas más comunes de "protesta" en este sentido eran las quejas (casi nunca públicas), que a veces se transformaban en acusaciones pesadas, y la falta de participación en el trabajo colectivo y en las asambleas.

La gente se lamentaba por no haber gozado del producto de su trabajo, pero al mismo tiempo se mostraba consciente y conforme a que el maíz producto colectivamente durante la guerra fuera entregado a la guerrilla ("...para mantener la tropa que defendían nuestros intereses", como dice un entrevistado). Y también estaba de acuerdo en distribuir a las viudas, los ancianos y los lisiados el maíz producido colectivamente. 
Se destacaba entonces una contradicción entre la adhesión de la gente a las motivaciones ideales y políticas por las cuales había trabajado colectivamente y su percepción de una frustración de sus intereses, su disolución por no haber visto el resultado de su esfuerzo. El trabajo colectivo era visto como algo lejano de sus intereses, algo dictado por criterios más políticos que económicos. Y ésto ayuda a comprender porqué la gente, una vez que terminó el conflicto y se acabaron las ayudas que garantizaban su sobrevivencia, dejó el trabajo colectivo y optó por el trabajo individual: "Nos quitaron la pacha y tuvimos que llenarnos el estómago de uno mismo" dijo un campesino. Quién le podría asegurar que trabajando colectivamente recibiría lo suficiente para sustentar a su familia?

La idea del trabajo individual en la milpa como único modo para garantizar su sobrevivencia era muy fuerte entre los habitantes de Copapayo. Tal concepción era tan arraigada que también quienes aceptaron trabajar para la comunidad o en la cooperativa pusieron como condición de seguir trabajando en su milpa. Lo ideal para ellos era una "mezcla" entre trabajo individual y colectivo (o cooperativo).

Aún la parte de socios de la cooperativa que consideraba el trabajo cooperativo diferente del colectivo por ser fuente de ganancia, no quería abandonar su milpa.

La preferencia hacia el trabajo individual y los obstáculos que ésta pone frente a los tentativas institucionales de implementar formas de trabajo colectivo en el agro salvadoreño han sido analizadas también por Segundo Montes: “...la ilusión de la inmensa mayoría de los campesinos es la de llegar a tener su parcela en propiedad, en la que cultiven lo que les guste y donde puedan tener una autonomía y seguridad familiar, produciendo lo necesario para autosubsistir. Hasta tal punto, que los intentos de modificaciones en la tenencia de la tierra que ha realizado el gobierno se han enfrentado con la actitud de los campesinos beneficiados, a los que han tenido que hacerles ciertas concesiones, como la de dejarle un lote en el que cultiven lo que les apetezca. Algo similar ha sucedido en las experiencias cooperativistas, que se han topado con una fuerte oposición de los cooperativistas al trabajo comunitario o colectivo, lo que ha marcado un límite a esas instituciones, y en su mayoría han tenido que conformarse con ser de ahorro y préstamo o de consumo. La experiencia de la actual reforma agraria, según los informes ya presentados, ha mostrado un fenómeno similar, y la oposición al trabajo colectivo, principalmente en antiguos pequeños propietarios y arrendatarios (en los que las expectativas y experiencia vivida habían reforzado esos elementos ideológicos), aunque menor en los antiguos colonos y asalariados, más acostumbrados al trabajo colectivo y con menos expectativas hacia la propiedad" ${ }^{41}$

Esta actitud generalizada se puede interpretar de la siguiente forma: frente a una situación de pobreza, incertidumbre y precariedad económica que está cuestionando la sobrevivencia misma del campesino, no hay espacio para otro riesgo más, es decir para la innovación. Así que el campesino tiende a repetir una 
elección económica segura, experimentada varias veces, transmitida por los padres, elección que Michael Lipton llama "algoritmo de la sobrevivencia"42 (y que en el caso de Copapayo es la milpa individual).

Ese comportamiento económico "tradicional" no es racional en sentido capitalístico, o sea de optimización en la asignación de los factores productivos, pero es racional si referido al objetivo del campesino, que no es la ganancia sino la sobrevivencia. El "algoritmo de la sobrevivencia" es una medida de defensa frente a una situación de escasez e inseguridad.

Obviamente no se quiere explicar la falta de participación al trabajo colectivo y a todas las actividades comunitarias por medio de este unido factor (o sea de la opción por la milpa individual en cuanto garantía tradicional de sobrevivencia).

Se ha visto como la tendencia a participar en una actividad colectiva exclusivamente en cambio de incentivos económicos podría haber sido impulsada por la costumbre a recibir ayudas y, al mismo tiempo, por la percepción del trabajador de no haber sacado provecho de su propio trabajo. La satisfacción de sus necesidades ha venido encontrado su respuesta principal en algo ajeno al trabajo colectivo: las ayudas durante la guerra, el trabajo individual antes y después de la guerra.

$\mathrm{Y}$ finalmente hay que considerar en qué forma han venido desarrollándose y cómo han sido percibidos el trabajo colectivo y la organización política.

La falta de democracia interna en la organización política (que aquí no queremos ni justificar, ni juzgar: solamente constatar) ha sido acompañada por una división del trabajo colectivo y cooperativo que replanteaba el tradicional esquema "patrón-mozos" (así apareció en la percepción de los habitantes de Copapayo), o bien derivada del típico esquema gerárquico "jefe-subordinados" tan familiar a los partidos de inspiración marxista, seguramente reforzado por la guerra y por la consecuente sobreposición de la organización política a la organización militar. En efecto, el trabajo colectivo se organizó en grupo de diez trabajadores, llamados "mozos", dirigidos por un jefe. Además, en la nueva cooperativa de ganado se destacaban entre sus miembros precisas relaciones gerárquicas correspondientes a una neta división del trabajo.

Es decir que la población parecía concebir sólo tres tipos de trabajo: el trabajo individual, que garantizaba autonomía, ${ }^{43}$ el trabajo del "jefe" y el trabajo subordinado, que la gente reconducía al del mozo o peón, o sea a una situación de subordinación que claro no era deseable si no era estrictamente necesaria, y más aún cuando los incentivos "ideales" y de emergencia (unirse contra el enemigo) que lo habían justificado estaban en crisis.

En efecto en 1992 se percibía en todos los niveles la transición de una etapa "político-militar" a una etapa "económica", en la cual el objetivo era el desarrollo económico. Esto se destacaba también en las entrevistas a miembros de las varias instituciones involucradas en el proceso, que tenían un papel importante 
en orientar el futuro económico y político de la comunidad: PROGRESO, CORDES, FEDECOOPADES y las FPL ${ }^{44}$ Estas hablaban de pasar "de las balas a las leyes", "de un eje político-militar a un eje económico", "de la disciplina militar a la disciplina administrativa y empresarial", "de la defensa de la vida al desarrollo de las condiciones de vida", etcétera.

Mirando al objetivo del desarrollo económico de las comunidades, éstas organizaciones expresaban la imposibilidad de prescindir del cultivo individual de la milpa, así que todas planteaban una forma de economía "mixta" que combinaría dos formas de producción: la producción familiar de granos básicos para garantizar la subsistencia y el trabajo colectivo y/o cooperativo en los sectores del ganado, de la agricultura intensiva y de la pequeña industria para impulsar el desarrollo.

Estas organizaciones - por lo menos en 1992 - no parecían dudar sobre las potencialidades económicas de la organización comunitaria. Su objetivo era el de favorecer el desarrollo económico de la comunidad por medio de la organización y de la canalización de recursos procedentes del gobierno y de organizaciones extranjeras.

Sin embargo, para que este proyecto tuviera éxito era necesario que la población estuviera de acuerdo y quisiera participar en la organización, porque sin su participación no se podría realizar su desarrollo. Los miembros de estas organizaciones que se entrevistaron no parecían tomar en cuenta la posibilidad de que la población separa el ámbito colectivo del ámbito familiar y que proyectaba en éste último sus intereses económicos, así que, con la nueva predominancia de "lo económico" sobre "lo político", prevalecieran las alianzas y los intereses familiares sobre aquellos comunitarios y se llegara a una cierta desorganización. Porque las alianzas comunitarias no se transfieren automáticamente del ámbito político e ideológico al ámbito económico.

Además esos entrevistados no tomaban en cuenta, o quizás no querían hablar, de las tendencias de la población hacia el cansancio, la falta de participación, la desorganización, el "regreso al individualismo" —de las cuales hablaba la misma gente de Copapayo.

La separación entre los intereses individuales-familiares y aquellos colectivos es un elemento fundamental y se pudo detectar en distintas ocasiones.

En primer lugar, algunas personas hablaban de la comunidad como algo ajeno, con quien tenían relaciones pero de la que no se sentían parte. Algunos pobladores hasta identificaban a la comunidad con la directiva.

Otros se contradecían, porque manifestaban estar en favor del trabajo colectivo, que consideraban un bien para la comunidad, pero ellos no querían participar porque les convenía más trabajar individualmente.

La falta de percepción de los intereses colectivos resultaba también de la 
poca consideración dada por la gènte a los bienes y servicios colectivos. Ninguno, al hablar de lo que poseía, hacia referencia a la tierra, la escuela, la clínica, el agua potable, el molino, etc. De la misma manera, ninguno enumeraba entre las ayudas recibidas las que eran de toda la comunidad, sino solamente los alimentos, la ropa y otros bienes recibidos personalmente por su familia. La escasa consideración de los bienes y servicios colectivos fue útil a la comprensión de otros dos fenómenos: el descuido de éstos y la respuesta negativa de los individuos a la pregunta si la comunidad les estaba ayudando en algo. (Todos decían que no, o a lo sumo decían que estaban recibiendo el crédito para los insumos y para emergencias, como una enfermedad grave. Las viudas admitían recibir el maíz). Pero las posibles interpretaciones de esta respuesta son varias:

-El verbo "ayudar" parecía significar "otorgar bienes para uso personal" seguramente por experiencias anteriores: en el refugio y en los dos primeros años de vida en Copapayo la "ayudas" eran los bienes que una familia recibía para poder sobrevivir.

-También cuando se sustituía el verbo "ayudar" con otras palabras, la respuesta no cambiaba: prevalecía la comparación con el pasado.

- Tal percepción era reforzada por el hecho que algunos servicios otorgados por la comunidad y que antes habían sido gratuitos, como la consulta médica, el transporte, la leche y la utilización del tractor y del molino, en 1992 se pagaban, así que ya no eran percibidos como facilitaciones por el hecho de vivir en comunidad. Aunque el precio de estas prestaciones era más bajo el mercado y el costo fue justificado por la directiva con la necesidad de pagar a quien daba esta prestaciones, la gente parecía percibirlas como bajo el mecanismo de "intercambio" y no "redistribución".

-Por último se puede decir que el único servicio totalmente gratuito dado regularmente y personalmente a la gente en 1992 era la educación, pero ésta no era percibida como una necesidad.

Antes de pasar al análisis del papel del "intercambio de mercado" en la economía de Copapayo, hay que mencionar que, además de la organización política a todo nivel (la organización comunitaria, PROGRESO, las FPL) y de las OUGS como FEDECOOPADES y CORDES, habían otras instituciones con un papel en la "redistribución": las ayudas internacionales y, al interior de la comunidad, la cooperativa. Y empezaba a tener un papel económico también el Plan de Reconstrucción Nacional, con todas las instituciones en éste involucradas: las antes mencionadas, el Gobierno y la Secretaría de Reconstrucción Nacional, la alcaldía, CREA Iong estadounidense que estaba comenzando un proyecto de construcción de vivienda) y su financiadora AID, etc.

De las ayudas internacionales ya se ha hablado. Sólo hay que agregar que en 1992 éstas se canalizaban casi todas por medio de CORDES, PROGRESO y 
FEDECOOPADES, o sea que ya no llegaban, como antes, directamente a la comunidad. Esto constituía una de las motivaciones principales de queja hacia estos organismos intermediarios por parte de la comunidad y de su directiva, porque ya no podían controlar "sus" fondos.

Por lo que concierne la cooperativa, cuya constitución fue implementada por FEDECOOPADES en septiembre de 1992, su actividad productiva principal era la cría de ganado, pero abarcaba también un proyecto de pesca promovido por la organización gubernamental CENDEPESCA. (Sin embargo este proyecto estaba ya en crisis en su fase de arranque debido al total desinterés de CENDEPESCA en su real desarrollo).

El surgimiento de la cooperativa respondía a varias necesidades: primero, la obtención de la personalidad jurídica para poder abrir el acceso a financiaciones gubernamentales y de otras instituciones. En segundo lugar, la cooperativa era necesaria para implementar un proyecto grande de cría de ganado de engorde financiado por CEE por medio de FEDECOOPADES.

A éstas motivaciones hay que agregar las de los individuos que decidieron entrar en la cooperativa (la actividad de la cría de ganado arrancaba con diez socios).

En efecto los socios entrevistados tenían las ideas confundidas y sobreponían a las razones "políticas" oídas en las asambleas, las motivaciones ideales típicas del trabajo colectivo ("hay que mantener la unión y la organización"), los intereses económicos individuales (la esperanza en una ganancia) y también muchas dudas... Tanto que a menudo eran ellos los que preguntaban a la investigadora.

La confusión y las respuestas contradictorias eran aún mayores para las perspectivas hacia el futuro, lo que iba a confirmar que la cooperativa era un proyecto externo, promovido para y no por la comunidad y aceptado por ésta con poca convicción - tanto que fueron necesarios algunos meses para convencer un grupo a impulsar el proyecto. La argumentación que los convenció fue que no se podía perder la ocasión de una financiación tan grande.

El ser ajeno a la cooperativa se hacía patente en las entrevistas a quien no era socio: la mayoría ni sabía qué era la cooperativa y creía que el trabajo colectivo y el trabajo cooperativo eran lo mismo, proyectando las mismas motivaciones ideológicas y las mismas críticas y desinterés individual. (Solamente a los socios les quedaba claro que la diferencia estaba en la ganancia. Pero tanto los socios como los no socios que pensaban asociarse en el futuro, no querían abandonar su milpa).

La cooperación como "planificada desde lo alto" bien forma parte del esquema de redistribución, así como su organización interna (propiedad y trabajo colectivos) y la participación de la directiva de la comunidad a las decisiones (había una misma directiva para la comunidad y para la cooperativa). 
Pero el salario diario dado a los trabajadores no socios (que eran pagados a precio de mercado) y el matiz "empresarial" de la actividad económica (con el objetivo de la comercialización y de la ganancia, la cual sería parcialmente invertida para expander la producción) parecen pertenecer al mecanismo de mercado.

\subsection{El intercambio y el papel del mercado.}

Hay que considerar el papel del intercambio de mercado en dos diferentes niveles: en las relaciones comerciales entre la comunidad (o sus individuos) y su entorno y en aquellas dentro de la comunidad.

Respecto a las relaciones comerciales con el entorno, la comunidad en 1992 compraba externamente muchos bienes y algunos servicios, para garantizar los servicios comunitarios (ej. gasolina para las lanchas, medicinas para la clínica, material de construcción, etc.). Esto ocurría sobre todo desde cuando las ayudas llegaban solamente bajo la forma de financiación. Estas "compras colectivas", expresión de una mezcla entre "intercambio" y "redistribución", eran hechas por la directiva o por alguien encargado por ella y el dinero procedía sobre todo de las ayudas financieras..$^{45}$

Las relaciones comerciales entre los individuos y el entorno se desarrollaban sobre todo en Suchitoto (y algunas veces en otros pueblos), donde la gente iba a comprar — sobre todo bienes de consumo - y a vender - parte del producto de su trabajo: maíz, ajonjolí, cerdos, gallinas y de vez en cuando un chivo o una vaca.

A excepción del ajonjolí, vendido después de la cosecha, es interesante destacar que generalmente la venta se daba cuando los individuos tenían que cubrir una necesidad específica. (Por ejemplo, una mujer vendía un cerdo porque su hijo se había enfermado, o vendía un medio de maíz para comprar los frijoles que se habían acabado). El objetivo de la venta y también de la compra no era la ganancia, sino el consumo, o bien la producción (la compra de una herramienta necesaria o de un animal, la cancelación de la deuda contraída para los insumos...): nos referimos a una economía de subsistencia.

Las únicas personas que compraban en Suchitoto con el fin de comercializar eran las vendedoras de las cinco tiendas de Copapayo (dos eran de la organización comunitaria y tres eran individuales). Estas compraban las mercancías a los mayoristas y las vendían en Copapayo a precios de mercado.

Además de Suchitoto y otros pueblos, también en Copapayo se desarrollaban a veces relaciones comerciales con gente externa: eran los comerciantes que llegaban a la comunidad para comprar ajonjolí, maíz, animales o para vender algunos productos.

Estos intermediarios eran y son llamados "coyotes" porque compran los productos agrícolas a bajo precio, disfrutando la oferta alta y el hecho que la gente vende por necesidad, y los revenden a las tiendas con una notable ganancia. 
Así que es evidente una forma de explotación de los campesinos por parte del mercado: hay un desequilibrio en las razones de intercambio entre los granos básicos vendidos por ellos y los bienes que compran. Esta situación ha ido agravándose por la política de precios del gobierno que ha liberalizado todos los precios a excepción de los granos básicos.

Por lo que concierne a las relaciones comerciales internas en la comunidad, las tiendas eran su "lugar institucionalizado", pero no eran su único canal: se daban también relaciones de intercambio entre familias, aunque eran más irregulares.

Se vendían y se compraban animales, productos agrícolas, algún servicio (sastrería y carpintería) y mano de obra para el trabajo agrícola. Pero ninguno estaba viviendo de la venta de su fuerza de trabajo. Todos los trabajadores poseían su milpa y cuando trabajaban como peones lo hacían para aumentar su ingreso. Además no necesariamente quien trabajaba para otros era el más pobre: podía ser el que ya había terminado su trabajo; un hombre rápido y capaz, buscando por mucha gente; un muchacho que podía dejar su milpa porque en ésta trabajaba su padre; o también un amigo, un compadre, un familiar a quien se pedía un favor y que a su vez buscaría apoyo en su milpa (en éste caso, se habla más de "reciprocidad" que de "intercambio").

Al mismo tiempo, quien contrataba mozos no siempre era el más rico: a veces lo hacía por necesidad (como en el caso de una viuda, de un padre anciano que no tenía hijos varones, de un hombre que tenia otro trabajo o que se había enfermado). Sin embargo, ésto no significa que no hubiera gente que contratara mozos por haberse enriquecido y haber cultivado mucha tierra: la idea de la utilización de peones como símbolo de bienestar era presente y bien se expresaba en la respuesta más común a la pregunta: “¿Usted contrata peones?", que era: "No, porque no tengo dinero". Y algunos veían en la utilización de peones el riesgo del regreso a la situación de antes, "...cuando el pobre explotaba el aún más pobre".

Pasando al "lugar institucionalizado" del mecanismo de intercambio, las tien-

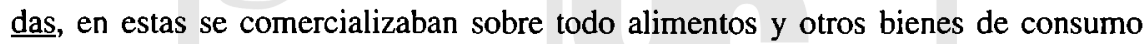
doméstico, pero su presencia no significaba que se vendían mucho, ya que la mayoría de la gente compraba muy poco por no tener dinero. A excepción de unos pocos bienes (ej. sal, azúcar, cal, jabón), las mercancías eran consideradas un "lujo" y la sobrevivencia cotidiana estaba garantizada por el maíz, los frijoles, el pescado y los huevos que las familias se proporcionaban directamente con su trabajo.

Sin embargo, aunque del mecanismo de intercambio no dependía la sobrevivencia de la población de Copapayo, éste mecanismo interfiría en la satisfacción de muchas necesidades, directa e indirectamente (o sea en el momento de producción): quien más quien menos, todos dependían de cualquier forma de la compra, de la venta y del dinero.

También estudiando la percepción subjetiva del papel del dinero en la vida 
económica de los habitantes de Copapayo, se destacó que generalmente el dinero no era visto como la fuerte de sobrevivencia, papel otorgado a la milpa y al trabajo del hombre. Sin embargo, la falta de dinero se percibía siempre como una fuerte limitación en la satisfacción de las necesidades familiares. (Hablando de sus consumos, la gente empezaba casi siempre la frase con "Cuando tengo dinero....").

Se consumía cuando se tenía dinero, pero al mismo tiempo se buscaba dinero cuando había que comprar algo necesario: con un préstamo o con la venta de un cerdo, una gallina o un medio de maíz se podía responder a una necesidad impelente.

Además, no se debe olvidar que se está generalizando, pero el papel del dinero y del mercado cambiaba mucho según las familia. Por ejemplo, era más importante para los asalariados, para las vendedoras y para las familias "improductivas" que para las familia que tenían una abundante producción agrícola. Por ésto no siempre una mayor circulación de dinero en una familia significaba un mayor bienestar. Al contrario, algunas viudas percibían su "dependencia del dinero" como síntoma de pobreza y precariedad económica: la primera fuente de riqueza era la producción agrícola, con el dinero como simple intermediario. (Mercancía-Dinero-Mercancía...)

\subsection{Conclusiones}

Desde el análisis anterior se puede concluir que no es posible definir una forma de integración dominante en la economía de Copapayo de 1992 ya que cambiaba según los aspectos económicos de la familia que se estaban considerando.

Así, al analizar la familia como unidad de producción, consumo y mutuo apoyo y como base de la economía de Copapayo, el papel central lo jugaría el mecanismo de reciprocidad.

Pero considerando que la producción agrícola familiar era permitida por una distribución centralizada de los medios de producción, que a la división familiar del trabajo se sobreponía una división del trabajo a nivel comunitario y que las ayudas internacionales habían tenido mucha importancia en el desarrollo económico de la repoblación, se destacaba la función fundamental de la forma de redistribución.

Por su parte, el mecanismo de intercambio adquiría importancia al pensar que muchas de las necesidades de los habitantes de Copapayo se satisfacían directa o indirectamente comprando y vendiendo mercancías.

Finalmente, no hay que olvidar la frecuente interacción de los tres mecanismos en moldear los movimientos apropiativos en Copapayo. (Por éjemplo, la redistribución se unía al intercambio en el comercio entre la comunidad y su entorno y a menudo se unía a la reciprocidad en la asignación de los puestos de trabajo). 


\section{Cuadro 2}

Las tres formas de integración económica en Copapayo en 1992

\begin{tabular}{lll}
\hline Forma de integración RECIPROCIDAD & REDISTRIBUCION $\begin{array}{l}\text { INTERCAMBIO } \\
\text { DE MERCADO }\end{array}$
\end{tabular}

Instituciones internas
y externas con un pa-
pel económico funda-
mental.

Instituciones con un Amistad papel económico se- Compadrazgo cundario.

\author{
Familia \\ parentesco
}

Vecindario

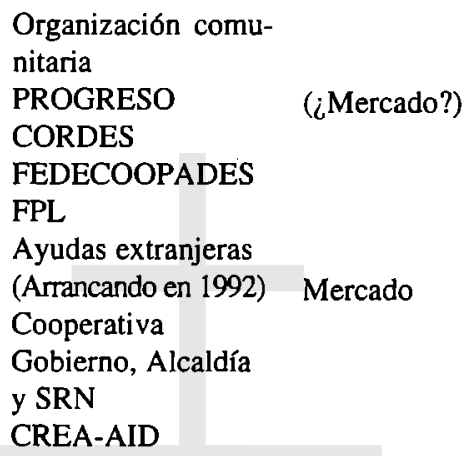

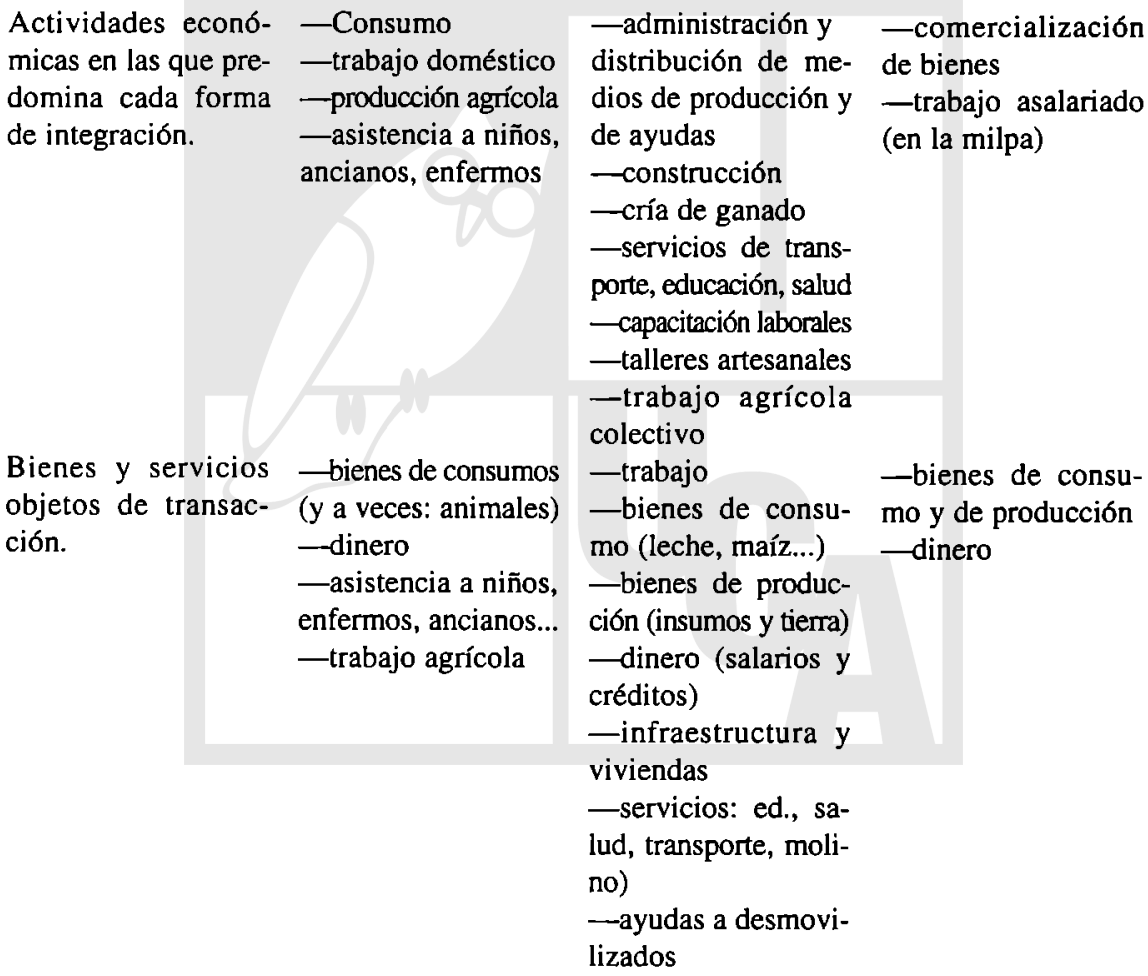




\section{Bibliografia}

A.A.V.V.: "Documento especial. Acuerdo de Paz", en ECA, n 519-520, En.-Feb. 1992 $n^{\circ} 21,01 / 03 / 1992$, IDESES.

L.A.: "La operación Fenix: despoblación y destrucción en el Cerro de Guazapa", en: $E C A, \mathrm{n}^{\circ}$ 435-436, En.-Feb. 1985.

M. Armas Molinas: La cultura pipil de Centro América, Ministerio de Educación, San Salvador 1974.

J. Arriola y D. Mena: "Alcances y límites de la concertación social en El Salvador", en: ECA, n 521, marzo 1992.

E. Baloyra: El Salvador en transición, UCA, San Salvador 1982.

K. D. Bailey: Metodi della ricerca sociale, II Mulino, Bologna 1985.

R. Benitez Manaut: "La guerra total en El Salvador. Efectos del conflicto bélico en la economía y la población", en: Revista Mexicana de Ciencias Políticas y Sociales, $\mathrm{n}^{\mathbf{0}}$ $132,1988$.

G. Bonazzi: Storia del pensiero organizzativo, Franco Angeli, Milano 1989.

D. Browning: El Salvador. La tierra y el hombre, Ministerio de cultura y comunicaciones, San Salvador 1987.

C. R. Cabarrus: "El Salvador. De movimiento campesino a revolución popular", in: Historia política de los campesinos latinoamericanos, vol. II, coord. P. González Casanova, Siglo XXI, México 1985.

J. Cáceres: "Estado, Sociedad y Política en un contexto de insurgencia popular. El Salvador 1980-87", en: CUIC-Documento de trabajo, $n^{\circ} 11$, agosto 1988, UES, San Salvador.

C. Clements: Guazapa. Testimonio de guerra de un médico norteamericano, UCA, San Salvador 1992.

Cripdes: Presentación del CRIPDES-CNR y perspectivas hacia el futuro, San Salvador 1992.

CRIPDES: Programa para el desarrollo organizativo de los desplazados, repatriados y repobladores, San Salvador 1992.

R. Dalton: El Salvador (Monografia), UCA, San Salvador 1992.

F. H. De Vera: "La resolución del proceso de negociaciones de paz", en: ECA, n' 531532, enero-febrero 1993.

Dies-Cenitec: "Las dimensiones de la pobreza extrema en El Salvador", Cuadernos de investigación, $\mathrm{n}^{\circ} \mathrm{l}$, febrero 1989.

W. H. Durham: Escasez y sobrevivencia en Centroamérica. Orígenes ecológicos de la guerra del fútbol, UCA, San Salvador 1988.

I. Ellacuría: "Factores endógenos del conflicto centroamericano: crisis económica y desequilibrios sociales", in: $E C A, n^{\circ} 456$, octubre 1986.

FMLN: "Proposta Economica dell'FMLN per lo Sviluppo e la Costituzione della Nuova società Salvadoregna", en: Sintesi Settimanale El Salvador, 8/6/1992.

P. Geoffroy Rivas: "El problema agrario en El Salvador. Una visión histórica", en: Reforma Agraria en El Salvador, ECA Nº. 207-208, julio-agosto 1972.

A. Goitia e L. Abrego: "Política macroeconómica y sus efectos en la agricultura y la seguridad alimentaria”, en: Realidad económico-social, № 17, sep-oct. 1990.

B. Hettne: Le teorie delo svilupp e il Terzo Mondo, ASAL, Roma 1986. 
J. H. Kolb e Edmund De S. Brunner: "Le comunità rurali", en: Sociología rurale, a cura di C. Stroppa, Hoelpi, Milano 1969.

W. Kula e Y. Kochanowicz: voce "Contadini", in: Enciclopedia, vol. III, Einaudi, Torino 1978.

M. Lipton: "La teoria del contadino come soggetto ottimizzante", en: L'agricultura nella teoria dello svilluppo economico, a cura di M. Gorgoni, II Mulino, Bologna 1983.

A. Marradi: Concetti e metodi per la ricerca sociale, La Giuntina, Firenz<e 1980.

I. Martín Baró: "Psicología del campesino salvadoren̄o", en: Reforma agraria en El Salvador, ECA, $\mathrm{n}^{\circ}$ 297-298, julio-agosto 1973.

I. Martín Baró: "Guerra y salud mental", en: Revista de Psicología de El Salvador, n 35, 1990.

I. Martín Baró: "La violencia política y la guerra como causas del trauma psicosocial en El Salvador", en: Revista de Psicología de El Salvador, n³ 35, 1990.

A. Martinelli: Economia e societá, Edizioni di Comunità, Milano 1987.

R. Mayorga Quiros: “Aspectos socio-económicos de la reforma agraria en El Salvador", en: Reforma agraria en El Salvador, ECA, $\mathrm{n}^{\circ} 297-298$, julio-agosto 1973.

I. Medina Nuñez: "Poderes populares locales en El Salvador, C.A.", en: CUIC-Documento de trabajo, $\mathrm{n}^{\circ} 11$, agosto 1988, UES, San Salvador.

Ministerio de Planificación y Coordinación del Desarrollo Económico y Social: Plan de Reconstrucción Nacional de El Salvador. Resumen ejecutivo, Febrero de 1992, República de El Salvador.

S. Montes: El Salvador 1985. Refugiados y desplazados, UCA, San Salvador 1985.

S. Montes: El agro salvadoreño (1973-1980), UCA, San Salvador 1986.

S. Montes: "El problema de los desplazados y refugiados salvadoreños", en: ECA, $\mathrm{n}^{\circ}$ 447-448, En.-Feb. 1986.

S. Montes: "El Salvador: la tierra, epicentro de la crisis", en: El problema agrario en El Salvador, Boletín de ciencias económicas y sociales, giugno 1986.

S. Montes: "Los límites y posibilidades que enfrenta la participación política en el campo salvadoreño", en ECA n 462-464 mayo-junio 1987.

S. Montes: "Los derechos económicos, sociales y culturales en El Salvador", in: $E C A, \mathrm{n}^{\circ}$ 476, junio 1988.

S. Montes: Refugiados y repatriados. El Salvador y Honduras, UCA, San Salvador 1989.

A. Montoya: "El Agro Salvadoreño antes y después de la Reforma Agraria", in: Cuadernos de investigación, $n^{\circ} 9$, junio 1991, DIES-CENITEC.

A. Montoya: "La nueva economía popular: una estrategia alternativa", in: $E C A, \pi^{\circ} 525$ 626, julio-agosto 1992.

R. A. Nisbet: La tradizione sociologica, La Nuova Italia, Firenze 1977.

G. Olano y O. A. Morales: "Interpretación socioeconómica de la política neoliberal", en: Realidad económico-social, $n^{\circ} 23$, sept.-oct. 1991.

W. Pelupessy: "Reforma agraria y sector agroexportador", en $E C A, n^{\circ} 461$, marzo 1987.

W. Pelupessy: "El sector agroesportador en El Salvador. La base económica de una oligarquía no fraccionada", en: Boletín de Estudios Latinoamericanos y del Caribe, $\mathrm{n}^{\circ}$ 43, dic. 1987.

W. Pelupessy: "La economía política del ajuste estructural", en: Realidad Económicosocial, $\mathrm{n}^{\circ} 15$, mayo-junio 1990.

L. Perrone: Metodi quantitativi della ricerca sociale, Feltrinelli, Milano 1985.

W. Pleitez: "Reforma agraria y desarrollo económico. Un examen crítico de la experien- 
cia salvadoreña", en: El Problema agrario en El Salvador, Boletín de ciencias económicas y sociales, junio 1986.

K. Polanyi: Economie primitive, arcaiche e moderne, Einaudi, Torino 1980.

K. Polanyi: La gran transformación. Los orígenes políticos y económicos de nuestro tiempo, Fondo de Cultura Económica, México 1992.

D. Pompejano: Storia e conflitti del Centroamerica. Gli stati d'allerta, Giunti, Firenze 1991.

M. R.: "Los resultados de la gestión económica de ARENA", en: ECA, n 504, oct. 1990.

R. Ruben: "El problema agrario en El Salvador: Notas sobre una economía agraria polarizada", Cuadernos de investigación, $\mathrm{n}^{\circ}$ 7, abril 1991, DIES-CENITEC.

M. Salazar Valiente: "El Salvador: crisis, dictadura, lucha... (1920-1980)" en: America Latina: historia de medio siglo, vol. II, Siglo XXI, México 1981.

J. H. Sánchez: Recuperando la vida con reforestación de usos multiples en los municipios de Suchitoto y_______ (Cabañas y Cuscatlán), El Salvador abril de 1992.

E. Sacho: I sentieri dell'audacia. Storia del Fronte Farabundo Marti per la Liberazione Nazionale, ed. Scuola Popolare "La Ghiaia", Berzano San Pietro 1990.

E. Sancho: "El Salvador frente a los desafíos del siglo XXI", in: $E C A, \mathrm{n}^{\circ} 511$, mayo 1991.

H. Schwartz e J. Jacobs: Sociología qualitativa, II Mulino, Bologna 1987.

P. A. Sorokin e C. C. Zimmerman: "Definizione di società rurale e società urbana", en: Sociologia rurale, a cura di C. Stroppa, Hoelpi, Milano 1969.

W. I. Thomas e F. Z. Znaniecki: “La famiglia contadina", en: Sociologia rurale, a cura di C. Stroppa, Hoelpi, Milano 1969.

W. I. Thomas e F. W. Znaniecki: "La lotta per la cosevazione del vecchio sistema sociale", en: Sociologia rurale, coord. C. stroppa, Hoelpi, Milano 1969.

E. Torres Rivas: Interpretación del desarrollo social centroamericano, EDUCA, San Salvador 197I.

F. Töennies: Comunità e società, Edizioni di Comunità, Milano 1979.

O. M. Velado: "Crecimiento demográfico y dinámica social en El Salvador", in: Realidad económico-social, $\mathrm{n}^{\circ} 14$, marzo-abril 1990.

M. Weber: Il metodo delle scienza storico-sociali, Einaudi, Torino 1958.

M. Weber: Economia e società, vol. I, Edizioni di comunità, Milano 1974.

\section{Notas}

1. Referencia a mi tesis de graduación en sociología económica titulada: "L'organizzazione economica di una comunità contadina. Il caso della repoblación di Copapayo in El Salvador", elaborada en el año académico 1992-93 en la "Università degli Studi" de Milano (Italia).

2. K. Polanyi: Economie arcaiche, primitive e moderne, coord. por G. Dalton, Einaudi, Torino 1980, pág. 140.

3. Habría también que preguntarse: "Cuáles son las necesidades humanas?" Así que se entraría en el largo debate sobre la posibilidad de definir necesidades objetivas y válidas para todos los seres humanos, a pesar de sus diferentes culturas. Según Bjöm Hettne (1987) el debate en torno a la definición de lo que es "necesidades humanas" surgió en los años '70, cuando los teóricos del desarrollo se dieron cuenta que el crecimiento económico no coincidía con el desarrollo porque no había llevado a 
la satisfacción de las necesidades humanas fundamentales de las grandes mayorías. En este marco surgieron dos principales enfoques. Según el primero, las necesidades fundamentales son iguales para todos los seres humanos y conciernen más que todo a la reproducción física; además son medibles y cuantificables. En el segundo enfoque las necesidades humanas están históricamente condicionadas y deben ser examinadas en cada contexto social específicio, por lo que no se puede llegar a una definición universal. Las necesidades humanas no son cuantificables y abarcan también los valores y la identidad cultural. Dicho en otras palabras, “...no es suficiente contestar que es necesario comer, también se debe considerar qué, cómo y con quién una persona va a comer". (B. Hettne: Le teorie dello sviluppo e il Terzo Mondo, Asal, roma 1987).

4. Popanyi, op. cit., pág. 143.

5. Ibídem. p. 143.

6. Ibídem, pág. 135.

7. Ibídem, pág. 140.

8. Con ésto no se niega la función de la intervención estatal, como es el caso del proteccionismo, en el desarrollo capitalista de muchos Estados (véase por ejemplo List y su diferenciación entre países "fist-comers" y "late-comers"), ni que otros factores a nivel ideológico puedan haber favorecido el desarrollo del capitalismo. (Ver por ejemplo Weber: "La ética protestante y el espíritu del capitalismo").

9. Karl Polanyi: La gran trasformación. Los orígenes políticos y económicos de nuestro tiempo, Fondo de Cultura Económica, México, 1992.

10. Polanyi obviamente expresa un juicio negativo sobre el prevalecer del utilitarismo y del economicismo en la sociedad de mercado. Escribe a propósito: "Una tal conversión forzada a una concepción utilitarista deformó fatalmente la concepción que el hombre occidental tenía de sí mismo". Y también: "soy favorable al retorno a aquella unidad de motivaciones que debería informar al hombre en su actividad cotidiana de productor, a la reabsorción del sistema económico en la sociedad, a la adaptación creativa de nuestros modos de vida al medio industrial. En todos estos aspectos la filosofía del laissez faire, con su corolario de la sociedad de mercado, cae en pedazos. Ella es responsable de la escición de la esencial unidad humana en el hombre "real" y a valores materiales, y en su "ideal" mejor parte. [...] Ahora tenemos que enfrentar el reto fundamental de restituir la vista tecnológica". (Polanyi: Economie primitive, arcaiche e moderne, pág. 71).

I1. Escribe Polanyi: "Mientras que la organización social corra por sus vías, no surgirán motivaciones económicas individuales; no tendrá que tenerse ninguna reduccion del esfuerzo personal; la división del trabajo se asegurará automaticamente; las obligaciones económicas se cumplirán puntualmente; y sobre todo se proveerán los medios materiales para una exhibición exuberante de abundancia en todos los festivales públicos. En tal comunidad queda descartada la idea del beneficio; se desprecia el regateo; se aclama como virtud la donación; no aparece la supuesta propensión a trocar e intercambiar. En efecto, el sistema económico es una mera función de la organización social". (Polanyi: La grande transformación..., p. 60).

12. En su primer libro, La gran transformación, Polanyi, al referirse a los griegos antiguos, introduce una cuarta forma de integración económica: el principio del hogar, que los griegos llamaron economía (el origen de la palabra "economía"). Este se refiere a la producción y el almacenamiento para la satisfacción de las 
necesiades de un grupo (familia, feudo, etc.) que está cerrado, o sea económicamente autosuficiente. En nuestra investigación no se ha tomado en consideración por varias razones:

- Cuando Polanyi elabora una teoría más sistematizada de las formas de integración económica no abarca la autárquica economía del hogar;

-Todas éstas formas son "tipo idelaes", puros, útiles para una construcción teórica pero que no existen en la realidad concreta, donde se encuentran mezclados entre sí. Sin embargo ésto parece ser válido sólo para los principios de reciprocidad, redistribución e intercambio, porque el rasgo principal que caracteriza la economía del hogar, o sea la autosuficiencia, excluye la posibilidad de mezcla con los otros principios, que en efecto son modos de transacciones.

-A nivel concreto, la realidad estudiada no tiene rasgos de autarquía, ni actualmente es posible imaginarse la asistencia de una economía cerrada.

13. Max Weber: Economia e società, vol. I Edizioni di Comunitá, Milano 1974, pág. 364.

14. Polanyi: economie primitive..., op. cit., pág. 148.

15. Se está hablando del intercambio de mercado, pero se debe subrayar que en otras economías existen otros tipos de intercambio, que tienen significados muy distintos. Polanyi menciona tres tipos de intercambio que se realizan o se realizaron en las socieades: el intercambio de donaciones, que une las partes en una relación de reciprocidad; el intercambio administrado, que se fundamenta en tratados entre gobiernos, excluye el regateo y se desarrolla a través de canales controlados por los gobiernos mismos; y el moderno intercambio de mercado, que sigue las líneas del mecanismo de la demanda, de la oferta y del precio flexible.

16. se pueden llamar también "modos socioeconómicos de transacción" porque describen transacciones (apropiaciones, asignaciones e intercambios internos y externos) de recursos humanos y materiales.

17. Ibídem, pág. 145.

18. Por ejemplo, en el caso de la reciprocidad, Polanyi escribe: "Es posible realizar las reciprocidades por medio de una repartición de las tareas de trabajo según específicas reglas redistributivas, como, por ejemplo, cuando se desarrollan cierta funciones turnándose. Igualmente a veces es posible realizar la reciprocidad a través de intercambios efectuado según razones establecidas de ante mano, para aportar ventajas a aquella parte que se encuentre momentáneamente en escasez en género de subsistencia [...]".

19. Esto es importante porque con los Acuerdos de Paz se ha venido desarrollando un proceso de reintegración política y económica a la realidad nacional de parte de las repoblaciones, las cuales había quedado bastante aisladas durante la guerra por estar ubicadas en las zonas conflictivas. Además, el Plan de Reconstrucción Nacional ha determinado una imporante canalización de recursos hacia esta zona, así que los cambios ocurridos en los dos últimos años son notables. Finalmente no hay que olvidar otros variables que han impulsado los cambios, como la movilización demográfica, los acontecimientos políticos (elecciones ante todo), etc. en otras palabras, se ha dado y sigue dándose un período de fuerte transición en todo nivel.

20. Hay que hacer algunas breves consideraciones al respecto. La tradición no se debería interpretar como ciega y estática repetición del pasado o como simple expresión de una mentalidad irracional, cerrada y atrasada, sino como una actitud psicológica 
de reacción frente a la inseguridad económica, una aplicación de experiencias acumuladas por años para poderse adaptar a un medio hostil, para defenderse en una situación de escasez de recursos y de precariedad y riesgos permanentes. (Precariedad debida no solo a la pobreza, a la injusta distribución de los recursos, a factores climáticos y ecológicos, sino también al particular período de transición en que se encuentra el país).

En este sentido el tradicionalismo, definido por Kula y Kochanowicz "una suma de conocimientos sobre la vida y los hombres acumulados con el transcurrir de los años y trasmitidos oralmente de generación en generación", se puede explicar con el hecho de que el riesgo continuo al cual está supeditada la población agrícola hace improponible añadir otro riesgo más: el de la innovación. "El tradicionalismo campesino, la inmutabilidad de este o aquel modo de acción por el simple hecho de que "así hacía mi padre" o que "el abuelo había recomendado hacerlo", o que, en general, "desde siempre se iba haciendo asi", tenía entonces sus fundamentos racionales: se trataba de reducir los riesgos conectados a la producción añadiendo a su propia experiencia la de la generaciones pasadas". (W. Kula e Y. Kochanowicz, "Contadini", en: Enciclopedia, vol. III, Einaudi, Torino 1978, pág. 904).

Esta explicación del tradicionalismo campesino puede ayudar a comprender muchas actitudes expresadas por los habitantes de Copapayo. Por ejemplo, el hecho de motivar con la costumbre sus comportamientos y sus deseos; o también, como se analizará más adelante, el hecho de no estar dispuestos a abandonar el tradicional cultivo de la milpa, que es símbolo de vida; o bien la desconfianza generalizada hacia la nueva cooperativa... De todos modos son muchos los factores que contribuyen a explicar estos fenómenos, que no se pueden ver com simple "repetición de la tradición". Además el arraigo a la tradición se puede interpretar también como la respuesta de una sociedad campesina amenazada por la desorganización social y el cambio. ( $\mathrm{Y}$ es cierto que los cambios producidos por la expansión del capitalismo en el agro salvadoreño a partir de los años '50 y luego por la guerra han venido cuestionando profundamente la organización social del agro salvadoreño). Thomas y Znaniecki escriben a propósito: "Los fenómenos de desorganización aparecen antes como simple alternativa: o el viejo orden o el caos completo. Sólo más tarde parece posible un orden social diferente [...]. El papel de prevenir o contrastar la desorganización $[\ldots]$ puede ser reducido en cualquier caso una fórmula sencilla: como inducir al individuos o a la comunidad a definir y resolver ciertas situaciones de manera igual al pasado, no obstante el cambio de condiciones o de actitudes...". (Thomas y Znaniecki y Znaniecki: "La lotta per la conservazione del vecchio sistema sociale”, en: Sociología rurale, coord. C. Stroppa, Hoelpi, Milano 1969, pp. 467-468).

21. Como escriben Kula y Kochanawicz (op. cit., pág. 910-911), "La vida del cantón supedita completamente al individuo bajo la comunidad [...], las conversaciones moldean la opinión del cantón sobre cada uno de sus habitantes, la mayoría de las veces sin posibilidad de apelación: verdadero o falso, este juicio se vuelve a realidad, [...] La sotomisión del individuo a la comunidad es una exigencia irrevocable [...] porque quien insiste en conservar su propio punto de vista amenaza del grupo y de consecuencia su misma existencia [...] El principio de unanimidad, el miedo al anticonformismo individual, el terror de la colectividad frente a quien piensa de manerà diferente son fenómenos que se detectan a menudo en las comunidades campesinas". 
A este punto habría que preguntarse: ¿Copapayo puede ser considerada una "comunidad" en el sentido tradicional? Cuánto las repercusiones debidas a la guerra, a la organización política, al desplazamiento la alejan del viejo cantón? La "comunidad" es algo nuevo, producto de la concientización y movilización religiosa y política, de la guerra civil y de la organización, o reproduce los rasgos tradicionales presentes en el agro salvadoreño?

Estas preguntas quedan abiertas, aunque se intentará dar algunas respuestas en el curso de este artículo hablando de las actitudes de los habitantes de Copapayo frente a la organización política, al trabajo colectivo y a la participación en las actividdes comunitarias.

22. Estos aspectos se analizan en el capítulo $\mathrm{V}$ de la tesis a que se está haciendo referencia que, lamentablemente no está traducida al español.

23. Se ha intentado reconstruir cual era la organización económica existente en la zona en los años '70 integrando las informaciones de muchos habitantes de Copapayo con los estudios de varios autores, como los de Segundo Montes, Ignacio Martín Baró, William H. Durham, Edelberto Torres Rivas, Carlos R. Cabarrús y David Browing. (Ver la bibliografía de la tesis que aparece al final del artículo).

24. Este proceso de semi-proletarización, favorecido por el gran crecimiento demográfico y la marginación de estos campesinos en las tierras más estériles, (las más fertiles habían sido agarradas por los cultivos para la exportación), se fue intensificando a partir de los años 50-60, con la profundización del capitalismo en el agro salvadoreño por la modernización y diversificación de los cultivos de exportación.

25. Ver el texto de O. Rodríguez: "La concepción del sistema centro-periferia", en La teoría del subdesarrollo de la CEPAL, Siglo XXI, México, 1983.

26. En muchas entrevistas, la gente piensa la difícil situación económica de Copapayo es debida a la guerra, que ha impedido el desarrollo de la comunidad no solo por haber destruido mucho recursos y haber matado a muchos hombres, sino también porque para defenderse había que invertir dinero, mano de obra potencial, productos agrícolas y otros bienes en la guerra misma.

27. Aquí no se van a tratar en detalle todos estos aspectos. Además habría que estudiarlos de manera más profundizada, porque las variables son muchísimas y porque a veces aparecen efectos contradictorios. (Por ejemplo, por lo que concierne la institución de la familia, por un lado la guerra parece haberla debilitada por la dispersión de sus miembros y por los cambios culturales; por otro lado, parece haberla reforzada, porque frente a las agresiones externas, que llegaron a amenazar la vida misma, y frente a las dificultades económicas, los vínculos familiares parecen haber adquirido mucha importancia: cada uno se apoyaba en el otro para sobrevivir.)

28. Hasta 1989 en Copapayo las ayudas proporcionaron todo lo necesario para vivir. Además permitieron el arranque de la producción agrícola (con donaciones que progresivamente han venido transformándose en créditos) y la construcción de la vivienda y de toda la infraestructura (agua, letrinas, plantas eléctricicas, escuela. clínica, guardería, bodegas, etc.). Han asegurado los transportes marítimos y terrenales, muchas maquinarias (tractores, molino, desgranadora...), los recursos y las capacitaciones necesarias para el funcionamiento de la escuela, la guardería y dos clínicas y aquellos necesarios para el desarrollo de varias actividades económicas, como sastrería, cría de ganado, carpintería y otras que ya no están funcionando, 
como: panadería, comedor, taller de bordado.

La importancia de las ayudas es cuantitativa y también cualitativa, porque han ido determinando las características de la organización económica de Copapayo. En efecto, según la directiva "el proyecto venía ya cuadrado": las decisiones al respecto no las tomaban los habitantes de Copapayo, sino las organizaciones nacionales y extranjeras que canalizaban estos recursos.

29. En más de una entrevista a miembros de la comunidad (un dirigente entre ellos), la posibilidad de recibir ayudas se presentó como una de las razones de la existencia misma de la comunidad; el retorno individual no habría permitido el acceso a las ayudas.

30. En las tesis ya mencionadas, se han analizado tres factores principales para explicar el conflicto:

- La extructura económica-social del agro salvadoreño en los años '70;

- el papel de la introducción de "nuevas" ideologías y de los actores externos en la concientización y organización de los campesinos;

- el Estado exclusor y represor y el papel político de los militares.

Se pueden ver al respecto los textos de Segundo Montes, Ignacio Ellacuría, Carlos

R. Cabarrús, Mario Salazar Valiente y Daniele Pompejano mencionados en la bibliografía final.

31. Sin embargo no todos se incorporaron a la lucha en los años '70. Muchos conocieron la organización sólo durante la guerra y entraron en ésta para defenderse frente a las masacres y los bombardeos de los militares, o bien empezaron a formar parte de la organización en el refugio de Honduras. Esto ayuda a interpretar los diferentes niveles de politización encontrados en 1992.

32. Ver I.M. Nuñez: Poderes Populares Locales en El Salvador, CUID-Documento de Trabajo $n^{\circ} 11$, UES, 1988 y C. Clements: Guazapa, Testimonio de guerra de un médico norteamericano, UCA, San Salvador 1992.

33. Más consideraciones al respecto son reportadas en el pártafo 2.6., dedicado al papel del mercado en la economía de Copapayo.

34. El papel y la forma concreta del principio de reciprocidad se estudiaron de dos maneras: investigando sobre la procedencia de los bienes y de los servicios utilizados por cada familia estudiada y también analizando la percepción subjetiva de las relaciones económicas por parte de los entrevistados. Se utilizó el mismo método también para los principios de redistribución e intercambio.

35. Se consideran las relaciones de reciprocidad, redistribución e intercambio entre la familia como unidad económica y su entorno, aunque es claro que los principios estén presente también dentro de la familia, en su división del trabajo y administración de los recursos. (Por ejemplo, el jefe de familia que centraliza los recursos y los administra según las necesidades de cada miembro responde al principio de redistribución, mientras que un ejemplo de principio de reciprocidad es que en la familia cada miembro cumple sus tareas dando por hecho que él aprovechará del trabajo de los otros).

36. Ver el próximo párrafo sobre la redistribución.

37. A este proposito es interesante notar que Thomas y Znaniecki, estudiando la familia campesina polaca del comienzo de siglo XX hacen las mismas consideraciones. (Su texto aparece en la bibliografía final).

38. En este sentido parece perfecta la interpretación de Weber sobre el papel de la 
familia y del vecindario en la comunidad rural: "El grupo doméstico es la comunidad que cubre lo necesario regular de bienes y de trabajo en la vida cotidiana. Partes importantes de lo necesario extraordinario de prestaciones en ocasiones particulares, en situaciones de necesidad y peligro, son cubiertas —en una economía de carácter agrario - por una acción de comunidad que se extiende más allá de cada economía doméstica, o sea por medio de la ayuda del "vecindario", [...] debemos destacar que también las relaciones estables de vecindario en los asentamientos rurales presentan, desde siempre, la misma desidencia: cada campesino está bien lejos del deseo de una ingerencia, por cuanto benévola pueda ser, en sus asuntos. La "acción de comunidad" no es la regla sino la excepción, por cuanto tipicamente recurrente. Esta es siempre menos intensiva y es más irregular que en la comunidad doméstica".

39. El primer año (1988-89) se produjeron colectivamente 10 manzanas de maíz (porque el trabajo mayor consistió en la construcción de las viviendas y de otras infraestructuras); en el segundo (1989-90) fueron 40 las manzanas cultivadas: la gente trabajaba colectivamente por 3 días cada semana. En 1990-91, se produjeron colectivamente 20 manzanas, con dos días semanales de trabajo por cada hombre; y en 1991-92 se cultivaron solamente 5 manzanas, con un día de trabajo cada dos semanas.

40. Por ejemplo, I. Martín Baró, Segundo Montes, Guerrit Huizer.

41. S. Montes: El agro salvadoreño (1973-1980), UCA, San Salvador 1986, p. 260.

42. M. Lipton: "La teoría del contadino come soggetto ottimizzante", en: Agricoltura nella teoria dello sviluppo economico, coord. M. Gorgoni, Il Mulino, Bologna 1983.

43. El deseo de autonomía en el trabajo, que es un rasgo típico del campesino arrendatario o pequeño propietario (o sea del "modo de producción campesino"), se detectó en muchas entrevistas.

Por ejemplo, la mayoría de la gente entrevistada declaró preferir el trabajo individual al colectivo o cooperativo porque el producto individual "uno lo puede recoger y comer cuando le dé la gana". Además algunos expresaron el deseo de autonomía no sólo en la administración del producto de su trabajo, sino también en el trabajo mismo. Ejemplar en este sentido es la frase de un hombre que dijo que lo ideal no es todo colectivo o cooperativo, ni todo individual, sino una mezcla, porque "...no es que uno puede estar todo el tiempo esclavo de la cooperativa".

También otras justificaciones dadas a la preferencia al trabajo individual reforzaban indirectamente indirectamente estas hipótesis, como el hecho de que en el trabajo colectivo "crecen los líos y las invidias porque algunos trabajan más y otros menos" o, como dice un dirigente, "trabajar solo colectivamente no es lo mejor. La experiencia nos dijo que no es lo mejor, porque si todos trabajamos colectivo, es una cosecha de crisis. Porque no todos damos nuestra real fuerza de trabajo... por una u otra razón no vamos al trabajo, buscando justificaciones. Es algo que uno no lleva adelante".

44. Así se ha introducido otra importante base institucional del mecanismo de redistribución: las organizaciones externas con un poder político y económico en la comunidad, o sea que en 1994 participaban en su planificación económica. No se va a profundizar el tema, pero vale la pena explicar un poco más quiénes son y cuál es su papel, - Las FPL (Fuerzas Populares de Liberación, uno de los cinco partidos 
del FMLN), en 1992 tenía, ante todo, el poder político en la zona por ser área exconflictiva, o estar bajo control de éste partido. Además muchos de los habitantes de Copapayo eran ex-combatientes o familiares de ex-combatientes, así que pertenecían o habían pertenecido al partido. Y, aunque los niveles de politización y de involucramiento eran muy diferentes en Copapayo, se puede decir que la gente políticamente hacía referencia directamente o indirectamente al partido, (que a su vez consideraba a la gente de las repoblaciones como parte de "su base"). Esto queda explícito en una entrevista a los dirigentes de la comunidad, los cuales al hablar de lo que era para ellos "democracia", la consideraban como un proceso de representación "desde la base hasta el vértice": la comunidad tenía que elegir a sus dirigentes, a los miembros de PROGRESO y al final al representante del partido...

Es difícil conocer el tamaño de la influencia política y económica que el partido ejercía directa e indirectamente (por medio de los otros organismos) sobre la comunidad. La herencia de la clandestinidad y de la sobreposición y conexión entre partido y organizaciones populares hacen la tarea aún más difícil.

Se hace solo un ejemplo, el más tangible (sin ponernos a analizar la situación durante la guerra, o sea los recursos entregados a la guerrilla y el papel del Frente en la organización económica y política de las repoblaciones): a partir de 1992 el programa de reinserción de los ex-combatientes en la vida civil ha ido determinando un flujo de recursos (bienes de consumo y de producción, créditos, capacitación, mano de obra) hacia la repoblación.

- PROGRESO (Promogestora de Comunidades Solidarias) en un organismos popular de representación de las repoblaciones ubicadas en el norte del departamento de Cuscatlán y sur-este del departamento de Cabañas, zona que durante la guerra estaba bajo control de las FPL.

PROGRESO surgió en mayo de 1988 para coordinar las comunidades que se iban formando por el retorno en la zona de refugiados y desplazados y para promover el surgimiento de nuevas repoblaciones. Con la firma de los Acuerdos de Paz, el papel del organismo cambió: por un lado el planteamiento de una democratización dentro de la organización política llevó a las elecciones de la directiva de PROGRESO por delegados de las comunidades: el objetivo era el de una verdadera representación política; por otro lado, el nuevo reto fue el de plantear e implementar un proyecto de desarrollo económico y social en la región, canalizando recursos nacionales e internacionales hacia las comunidades.

Esto significaba que en 1992 el organismo tenía un importante papel en la economía de Copapayo, en cuanto promotor y supervisor de los proyectos de desarrollo, intermediario entre la comunidad y las instituciones nacionales y extranjeras y también autoridad que tomaba decisiones concernientes a la comunidad.

Obviamente todo éso ha favorecido el surgimiento de conflictos de poder y de interés entre entre el organismo y la directiva comunitaria, que sentía una limitación en su poder decisional y en su acceso a los fondos. La razón de mayor queja era la desviación de ayudas llegadas para Copapayo (que era la comunidad más antigua y más famosa) hacia comunidades más jóvenes y más pobres. Pero ¿porqué la directiva y la gente se quejaban? Primera hipótesis: porque Copapayo no tenía una visión global del desarrollo de la zona y una actitud de solidaridad entre comunidades. Segunda hipótesis, que no contradice la primera: las decisiones de cómo emplear los recursos eran tomadas por PROGRESO sin consultar a la comunidad. 
(Esto es también el punto de vista de la directiva).

PROGRESO forma parte de CRIPDES, organismo nacional que agrega a todos a los organismos que representan a las repoblaciones de las FPL en las diferentes regiones.

CORDES (Fundación para la Cooperación de Repobladores y desplazados de El Salvador) surgí en 1988 desde CRIPDES, como organismo a éste complementario que se especializaría en la gestión, administración y ejecución de proyectos para la consolidación económica de la repoblaciones, dejando a CRIDES un papel más político y organizativo. Con el surgimiento de PROGRESO y de los organismos regionales, su función ha sido limitada. En cierto sentido, el significado es distinto, pero la función económica de CORDES y la de PROGRESO no son muy diferentes. Esto en 1992 parecía crear una cierta competencia entre los dos organismos: PROGRESO quería que las ayudas llegaran directamente a él, en cuanto representante de las comunidades, sin pasar por la mediación de CORDES a nivel nacional. Pero ésto significaría para CORDES no tener ya razón de existir.

Finalmente se detectó un conflicto de interees también entre PROGRESO y FEDECOOPADES, que hubiera querido tener una relación directa con la comunidad, como hacía antes de la formación de PROGRESO. (En este snetido en 1992, con la formación de la cooperativa, parecía desarrollarse un "juego de alianzas" entre la directiva y DECOOPADES para contrastar el dominio de PROGRESO).

FEDECOOPADES (Federación de Asociaciones Cooperativas de Producción Agropecuaria de El Salvador) surgió en 1980 para coordinar la cooperativas impulsadas por la Reforma Agraria y por la iniciativa de la Iglesia progresista. En 1992 abarcaba 70 cooperativas, ubicadas sobre todo en las zonas controladas por el FMLN. Su papel era el de formar y asesorar a las cooperativas y en este sentido impulsó la formación de la cooperativa en Copapayo en 1992. Sin embargo, su apoyo económico a Copapayo había empezado antes. (En efecto desde 1981 la Federación había venido trabajando con los desplazados y después con los repobladores, para favorecer su reintegración económica y social y orientarlos hacia el cooperativismo). A partir de 1987 FEDECOOPADES había venido financiando - antes directamente y después por medio de PROGRESO- el desarrollo de la producción agrícola y de los talleres de sartería, zapatería, carpintería. Así, había tenido un papel económico importante en la comunidad, aunque a nivel político su papel era marginal con respecto a las FPL y a PROGRESO.

45. Lo mismo valía para la cooperativa, que estaba comprando afuera los terneros, el alambre, las vacunas, etc., y vería el ganado engordado. 